\title{
Flora da Bahia: Hirtella (Chrysobalanaceae)
}

\section{Renata Asprino $^{1 *}$ \& André Márcio Amorim ${ }^{1,2, a}$}

${ }^{1}$ Programa de Pós-Graduação em Botânica, Universidade Estadual de Feira de Santana, Feira de Santana, Bahia, Brasil.

${ }^{2}$ Departamento de Ciências Biológicas, Universidade Estadual de Santa Cruz, Ilhéus \& Herbário CEPEC, Centro de Pesquisas do Cacau, Itabuna, Bahia, Brasil.

\begin{abstract}
Resumo - É apresentado o tratamento taxonômico de Hirtella (Chrysobalanaceae) para o estado da Bahia, Brasil. São reconhecidas 14 espécies; Hirtella bicornis é citada pela primeira vez para a Bahia e $H$. prancei foi descrita originalmente a partir deste estudo. O tratamento inclui uma chave de identificação para as espécies, descrições e comentários sobre os táxons, além de ilustrações e mapas de distribuição geográfica das espécies na Bahia. É apresentada, também, uma chave de identificação para os gêneros de Chrysobalanaceae que ocorrem no estado.

Palavras-chave adicionais: Brasil, florística, Malpighiales, Região Nordeste, taxonomia.
\end{abstract}

Abstract (Flora of Bahia: Hirtella (Chrysobalanaceae)) - The taxonomic treatment of Hirtella (Chrysobalanaceae) from Bahia State, Brazil, is presented. We recognize 14 species; H. bicornis is recorded for the first time in the state and H. prancei was originally described from this study. The treatment includes an identification key to species, descriptions and comments on taxa, as well as illustrations and geographic distribution maps of species in Bahia. An identification key to the genera of Chrysobalanaceae in the state is also provided.

Additional key words: Brazil, floristics, Malpighiales, Northeast Region, taxonomy.

\section{CHRYSOBALANACEAE}

Árvores, arvoretas ou arbustos. Folhas simples, alternas, margem inteira; lâmina glabra ou pilosa; pecíolo com ou sem glândulas; estípulas laterais, axilares ou adnatas ao pecíolo, caducas a persistentes. Inflorescências simples ou compostas; bracteadas. Flores bissexuadas ou raramente unissexuadas, actinomórficas ou zigomórficas, períginas; receptáculo curto a alongado devido ao desenvolvimento de um hipanto; disco nectarífero formando uma estrutura anelar a tubular na extremidade do receptáculo; cálice 5-mero, dialissépalo, sépalas eretas ou reflexas; corola 5-mera ou ausente, dialipétala; estames 3-100(-300), inseridos na margem do disco, dispostos em círculo ou unilateralmente, inclusos a exsertos, filetes filiformes, livres ou unidos entre si, glabros ou pilosos; ovário súpero, 1-3-carpelar, frequentemente com apenas 1 carpelo desenvolvido, inserido na base, meio ou ápice do receptáculo, 1- ou 2-locular, 2-ovulado, placentação basal, estilete ginobásico, filiforme. Frutos drupas carnosas ou secas, epicarpo liso, rugoso ou verrucoso, glabro ou piloso, endocarpo espesso ou delgado, fibroso ou ósseo.

Chrysobalanaceae pertence à ordem Malpighiales (Xi et al. 2012) e compreende 19 gêneros e aproximadamente 530 espécies (Prance \& Sothers 2003a; Sothers et al. 2014). Apresenta distribuição pantropical, com representantes nas Américas, África e Ásia. No entanto, mais de dois terços das espécies ocorrem na região neotropical, desde o sudeste dos

\footnotetext{
*Autora para correspondência: renata.asprino@hotmail.com; aamorim.uesc@gmail.com

Editor responsável: Alessandro Rapini

Submetido: 31 maio 2016; aceito: 11 out. 2016

Publicação eletrônica: 24 out. 2016; versão final: 28 out. 2016
}

Estados Unidos até o sul do Brasil e Paraguai (Prance \& Sothers 2003a). Dos oito gêneros de Chrysobalanaceae que ocorrem no Brasil, apenas Acioa Aubl. e o recém descrito Gaulettia Sothers \& Prance, restritos à região amazônica (Sothers et al. 2014, 2016), não estão representados na Bahia.

Por ser o primeiro tratamento taxonômico de Chrysobalanaceae para a flora da Bahia, é apresentada aqui uma chave de identificação para os gêneros que ocorrem no estado, elaborada com base em literatura específica (Prance 1972; Prance \& White 1988; Prance \& Sothers 2003a,b).

\section{Chave para os gêneros na Bahia}

1. Ovário unilocular, na base do receptáculo.

2. Pétalas 5; estames exsertos, unidos na base em grupos, filetes pilosos; drupas carnosas, endocarpo com 4-8 linhas longitudinais

2'. Pétalas 5 ou ausentes; estames frequentemente inclusos, às vezes exsertos, livres, filetes glabros; drupas carnosas ou secas, endocarpo sem linhas longitudinais

Licania

1'. Ovário uni ou bilocular, no ápice do receptáculo.

3. Estames inclusos; ovário bilocular.

4. Face abaxial da lâmina foliar com criptas estomatais cobertas por tricomas entrelaçados; brácteas e bractéolas convexas, envolvendo grupos de botões florais; drupas com epicarpo verrucoso e endocarpo com dois obturadores basais

Parinari

4'. Face abaxial da lâmina foliar sem criptas estomatais; brácteas e bractéolas patentes, não envolvendo grupos de botões florais; drupas com epicarpo liso e endocarpo sem obturadores basais Exellodendron 
3'. Estames exsertos; ovário unilocular.

5. Flores 7-30 mm compr.; estames 14-125, dispostos em círculo ou semicírculo; drupas carnosas ou secas, endocarpo sem linhas longitudinais

Couepia

5'. Flores 3-10 mm compr.; estames 3-9, dispostos unilateralmente; drupas carnosas, endocarpo com 4-7 linhas longitudinais

Hirtella

\section{Hirtella L.}

Árvores, arvoretas ou arbustos. Folhas com lâmina glabrescente ou pilosa, frequentemente com glândulas esparsas ou concentradas na base e/ou no ápice; pecíolo eglandular; estípulas laterais. Inflorescências simples ou compostas; pedicelos geralmente mais longos que o tubo do receptáculo; brácteas e bractéolas com ou sem glândulas sésseis ou estipitadas. Flores bissexuadas, zigomórficas; receptáculo campanulado a cilíndrico, levemente giboso, internamente glabro exceto por tricomas reflexos próximos à extremidade; disco nectarífero formando um anel bem definido na borda do receptáculo; cálice 5-mero, sépalas frequentemente reflexas; corola 5-mera, caduca; estames 3-9, dispostos unilateralmente, exsertos, filetes livres, glabros, frequentemente com estaminódios diminutos opostos aos estames; ovário inserido no ápice do receptáculo, 1-carpelar, 1-locular, estilete parcialmente piloso. Drupas carnosas, epicarpo liso, glabro ou piloso, endocarpo delgado, com 4-7 linhas longitudinais de deiscência, frequentemente visíveis no epicarpo dos frutos imaturos ou de material herborizado.

Hirtella é o segundo maior gênero de Chrysobalanaceae, com 107 espécies; das quais, 105 ocorrem em regiões tropicais e subtropicais das Américas, uma no leste da África e uma em Madagascar (Prance \& Sothers 2003b). No Brasil, são registradas 68 espécies, apresentando maior diversidade na região amazônica (Sothers et al. 2016). $\mathrm{Na}$ Bahia, foram encontradas 14 espécies de Hirtella.

\section{Chave para as espécies}

1. Inflorescências racemosas.

2. Folhas com nervura principal plana ou impressa e secundárias impressas na face adaxial; estípulas estreitamente triangulares a triangulares; flores com sépalas eretas.

3. Ramos jovens e inflorescências densamente velutinos (Figura 12A); lâmina foliar 10,3-18 cm larg., face adaxial bulada, face abaxial eglandular; bractéolas eglandulares; estames 19,5-22,5 mm compr.

10. $\mathrm{H}$. prancei

3'. Ramos jovens e inflorescências hirsutos a densamente hirsutos (Figura 12F); lâmina foliar 4,2-9 $\mathrm{cm}$ larg., face adaxial plana, face abaxial com glândulas discoides; bractéolas com glândulas na margem (Figura 9I); estames 11-14 mm compr.

12. H. santosii

2'. Folhas com nervuras principal e secundárias levemente salientes a salientes na face adaxial; estípulas lanceoladas ou lineares; flores com sépalas reflexas.

4. Ramos, pecíolos e inflorescências lanosos quando jovens (Figura 10D); brácteas 4,5-5,5 mm compr.; estames 8, filetes brancos; drupas com epicarpo densamente pubescente

9. H. martiana

4'. Ramos, pecíolos e inflorescências pubescentes ou hirsutos quando jovens; brácteas 1,2-3 mm compr.; estames 3-6, filetes róseos ou lilás; drupas com epicarpo glabrescente a esparsamente pubescente.

5. Indumento esparsamente hirsuto a hirsuto nos ramos jovens e nervuras na face abaxial das folhas; estípulas 6-11 mm compr.; lâmina foliar com 9-14 pares de nervuras secundárias.

6. Ramos jovens hirsutos (Figura 2A); lâmina foliar 1,8-3,5 cm larg.; bractéolas triangulares com uma glândula séssil no ápice (Figura 2C); estames 3 ou 4

1. H. angustifolia

6'. Ramos jovens esparsamente hirsutos a glabrescentes (Figura 9J); lâmina foliar (2,8-)3,2-4,9 cm larg.; bractéolas reduzidas a uma ou duas glândulas estipitadas no pedicelo (Figura 9K); estames 5 ou 6

13. H. sprucei

5'. Indumento esparsamente pubescente a pubescente nos ramos jovens e nervuras na face abaxial das folhas; estípulas 3-6 mm compr.; lâmina foliar com 6-9 pares de nervuras secundárias.

7. Ramos jovens e inflorescências esparsamente pubescentes a glabrescentes (Figura 2K); brácteas e bractéolas com gotículas de secreção translúcida na margem (Figura 2L); receptáculo floral estreitamente campanulado

7. H. gracilipes

7'. Ramos jovens e inflorescências pubescentes (Figura 9G); brácteas e bractéolas frequentemente com glândulas, mas nunca com gotículas de secreção translúcida; receptáculo floral cilíndrico (Figura 9F)

11. H. racemosa

1'. Inflorescências corimbosas, paniculadas ou tirsoides.

8. Flores com 3 estames.

9. Estípulas 5-5,5 mm compr.; lâmina foliar 6,4-11,8 cm compr., ápice atenuado a acuminado; estames ca. $18 \mathrm{~mm}$ compr., filetes roxo-azulados

9'. Estípulas 1,5-2,4 mm compr.; lâmina foliar 2,7-5,6 cm compr., ápice arredondado, mucronado, retuso ou raramente agudo; estames 5-8 mm compr., filetes brancos. 
10. Árvores, 5-26 m alt.; lâmina foliar com a base aguda a cuneada, coriácea, margem revoluta; inflorescências tirsoides; bractéolas espatuladas, com glândulas estipitadas no ápice (Figura 2D) ....

2. H. bahiensis

10'. Arbustos ou subarbustos, até $2 \mathrm{~m}$ alt.; lâmina foliar com a base arredondada a subcordada, cartácea, margem plana; inflorescências corimbosas compostas (Figura 4J); bractéolas triangulares, eglandulares 5. H. corymbosa

8 '. Flores com 5-7 estames.

11. Lâmina foliar com a face abaxial velutina ou pubescente; bractéolas com glândulas estipitadas em toda a margem (Figura 2G, J).

12. Pecíolo 0,5-2 mm compr.; lâmina foliar com ápice arredondado, mucronado, retuso ou raramente agudo, 3,2-6,8 cm compr., face adaxial com nervuras secundárias a quaternárias levemente salientes, eglandular; flores com receptáculo estreitamente campanulado; sépalas eretas

12'. Pecíolo 3-5 mm compr.; lâmina foliar com ápice atenuado a acuminado, $(6,5-) 8,5-15 \mathrm{~cm}$ compr., face adaxial com nervuras secundárias a quaternárias impressas, com glândulas na base (Figura 2I); flores com receptáculo cilíndrico; sépalas reflexas

6. H. glandulosa

11'. Lâmina foliar com a face abaxial glabrescente, às vezes com nervuras esparsamente pubescentes; bractéolas eglandulares ou com uma glândula estipitada no ápice.

13. Ramos jovens e inflorescências esparsamente pubescentes; estípulas $2-3,8 \mathrm{~mm}$ compr.; pecíolo 0,5-1 mm compr.; lâmina foliar 2,2-3,8 cm larg.; inflorescências paniculadas, 1-4 cm compr.; brácteas e bractéolas triangulares, eglandulares

3. H. bicornis

13'. Ramos jovens e inflorescências esparsamente hirsutos a glabrescentes (Figura 9A); estípulas 4,55,5 mm compr.; pecíolo 1-5 mm compr.; lâmina foliar 4,4-9,7 cm larg.; inflorescências corimbosas compostas, 4-7 cm compr.; brácteas e bractéolas oblongas, com uma glândula longamente estipitada no ápice (Figura 9B)

8. H. insignis

1. Hirtella angustifolia Schott ex Spreng., Syst. Veg. (ed. 16) 4(2, Cur. Post.): 341. 1827.

Figuras 1 e 2A-C; Prance (1972: fig. 50).

Árvores ou arbustos, $2-8 \mathrm{~m}$ alt; ramos jovens hirsutos, ocasionalmente lenticelados. Folhas com lâmina lanceolada a estreitamente oblonga, base subcordada, ápice agudo a atenuado, 9-15,6 × 1,8-3,5 $\mathrm{cm}$, membranácea a cartácea, margem plana, 10-14 pares de nervuras secundárias; face abaxial glabrescente, nervuras hirsutas, glândulas discoides esparsas, nervura principal saliente, as secundárias levemente salientes; face adaxial glabrescente, nervuras glabrescentes, eglandular, nervuras principal a quaternárias levemente salientes; pecíolo $2,5-4 \mathrm{~mm}$ compr.; estípulas lineares, 7-11 $\mathrm{mm}$ compr., eglandulares. Inflorescências racemosas, 13,5-25 cm compr., pubescentes; brácteas estreitamente triangulares a lanceoladas, $1,8-2,8 \mathrm{~mm}$ compr., caducas, ocasionalmente com glândula séssil no ápice; pedicelos 4-5,5 $\mathrm{mm}$ compr., eglandulares; bractéolas triangulares, 0,8-1,2 mm compr., caducas, glândula séssil no ápice. Flores 5-7 mm compr.; receptáculo campanulado; sépalas 4-4,5 $\mathrm{mm}$ compr., reflexas, margem eglandular; pétalas 3-4 mm compr., alvas a lilás; estames 3 ou $4,15-18 \mathrm{~mm}$ compr., filetes lilás; estilete 16-20 mm compr., hirsuto até o $1 / 4$ basal. Drupas obovoides, $16-19 \times 10-11 \mathrm{~mm}$, epicarpo glabrescente.

Hirtella angustifolia ocorre nos estados de São Paulo, Rio de Janeiro e Bahia (Prance \& Sothers 2003b). G8, H8, I8: floresta ombrófila densa e floresta de tabuleiro. Coletada com flores de fevereiro a julho e com frutos em julho e outubro.
Material selecionado - Itagibá, Mata da Antena, $14^{\circ} 10^{\prime} 02^{\prime \prime} \mathrm{S}$, 39 42'40"W, 30 maio 2012 (fl.), C.E. Ramos 209 (ALCB); Itamaraju, assentamento Pedra Bonita, $16^{\circ} 50^{\prime} 19^{\prime \prime} \mathrm{S}, 39^{\circ} 37^{\prime} 56^{\prime \prime} \mathrm{W}$, 13 dez. 2007 (fl.), R.A.X. Borges et al. 863 (CEPEC, RB); Una,

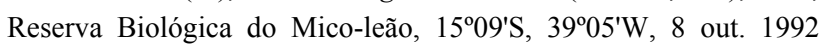
(fr.), A.M. Amorim et al. 848 (CEPEC); Uruçuca, área do inventário do plano manejo do Parque Estadual da Serra do Conduru, 14'29'59"S, 3906'54"W, 18 mar. 2004 (fl.), P. Fiaschi et al. 2065 (CEPEC, HUESC, RB, SPF).

Hirtella angustifolia assemelha-se a $H$. sprucei Benth. ex Hook.f. por apresentar frequentemente lâminas foliares estreitamente oblongas, estípulas lineares de 6-11 mm de comprimento, subpersistentes, e inflorescências racemosas. A distinção entre as duas espécies é complexa, principalmente devido à existência de intermediários entre os dois extremos da variação morfológica. A partir da análise dos espécimes na Bahia é possível diferenciar $H$. angustifolia de $\mathrm{H}$. sprucei pelo indumento mais denso nos ramos jovens e pecíolos (hirsuto vs. esparsamente hirsuto a glabrescente), folhas geralmente mais estreitas $[1,8-3,5$ vs. $(2,8-) 3,2-4,9 \mathrm{~cm}$ larg. $]$ e com mais pares de nervuras secundárias (10-14 vs. 9-11 pares), bractéolas triangulares com uma glândula apical (vs. bractéolas reduzidas a uma glândula estipitada no pedicelo), e flores com mais estames ( 3 ou 4 vs. 5 ou 6 ).

2. Hirtella bahiensis Prance, Fl. Neotrop. Monogr. 9: 307. 1972.

Figuras 2D e 3; Prance (1972: fig. 39).

Árvores, 5-26 m alt; ramos jovens pubescentes, lenticelados. Folhas com lâmina obovada a elíptica, 
base aguda a cuneada, ápice arredondado, retuso ou raramente agudo, 2,7-5,6 × 1,5-2,8 cm, coriácea, margem revoluta, 5-7 pares de nervuras secundárias; face abaxial esparsamente pubescente, nervuras esparsamente pubescentes, glândulas discoides esparsas, nervura principal saliente; face adaxial glabrescente, nervuras glabrescentes, eglandular, nervuras principal a quaternárias levemente salientes; pecíolo 1-2 mm compr.; estípulas estreitamente triangulares, 2-2,4 $\mathrm{mm}$ compr., eglandulares. Inflorescências tirsoides, 5-11,5(-14) cm compr., pubescentes; brácteas triangulares, 3-3,6 $\mathrm{mm}$ compr., persistentes, eglandulares; pedicelos 1-2 $\mathrm{mm}$ compr., eglandulares; bractéolas espatuladas, 2,5-4,2 $\mathrm{mm}$ compr., persistentes, 3-6 glândulas estipitadas no ápice. Flores 6-7 $\mathrm{mm}$ compr; receptáculo tubular; sépalas 3,5-4 mm compr., eretas, margem eglandular; pétalas 4-4,2 mm compr., brancas; estames 3, 7-8 mm compr., filetes brancos; estilete 8-10 $\mathrm{mm}$ compr., hirsuto até a $1 / 2$ basal. Drupas obovoides, ca. $19 \times 9$ $10 \mathrm{~mm}$, epicarpo esparsamente pubescente a glabrescente.

Hirtella bahiensis ocorre no litoral dos estados da Bahia e do Espírito Santo (Prance \& Sothers 2003b; Sothers et al. 2016). D9, F8, G8, I8: floresta ombrófila densa e restinga. Coletada com flores de agosto a dezembro e com frutos de outubro a janeiro.

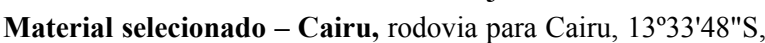
3902'98"W, 13 nov. 2003 (fl.), J.L. da Paixão 331 (CEPEC, RB);

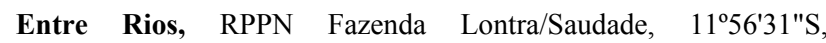
3805'04"W, 5 out. 1997 (fl.), N.G. Jesus et al. 159 (ALCB, HRB, HUESC, HUEFS); Ilhéus, rodovia Ilhéus-Una, Km 11, 14²7'S, 3902'W, 6 dez. 1984 (fl.), R. Voeks 72 (CEPEC); Maraú,

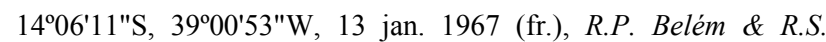
Pinheiro 3094 (parátipo CEPEC); Porto Seguro, arredores da

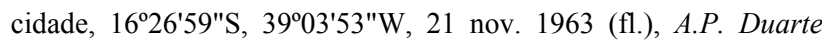
8029 (parátipos CEPEC, RB); Santa Cruz Cabrália, 16²16'41"S, 3901'29"W, 31 out. 1966 (fl.), R.P. Belém \& R.S. Pinheiro 2756 (isótipos CEPEC, RB); Una, Rebio de Una, 15¹0'18"S, 3903'40"W, nov. 2013 (fl.), R.B. Oliveira 53 (CEPEC); Uruçuca, área do inventário do plano manejo do Parque Estadual da Serra do

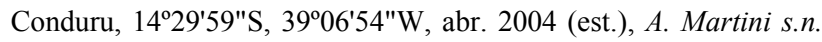
(CEPEC 122819).

Hirtella bahiensis pode ser reconhecida dentre as espécies na Bahia por apresentar os ramos conspicuamente lenticelados, pubescentes quando jovens, estípulas pequenas (2-2,4 $\mathrm{mm}$ compr.) e caducas, lâminas foliares frequentemente obovadas, coriáceas, com a margem revoluta, e bractéolas espatuladas, com 3-6 glândulas estipitadas no ápice. Além disso, as flores possuem sépalas eretas, pétalas e filetes brancos e três estames curtos (7-8 mm compr.).

3. Hirtella bicornis Mart. \& Zucc., Abh. Math.-Phys. Cl. Königl. Bayer. Akad. Wiss. 1: 377. 1832.

Figuras 4A-D e 5.

Árvores ou arbustos, 2-13 m alt; ramos jovens esparsamente pubescentes, lenticelados. Folhas com lâmina elíptica a oblonga, base obtusa a arredondada ou cuneada, ápice acuminado, 4,5-10 × 2,2-3,8 cm, cartácea, margem plana, 8-10 pares de nervuras secundárias; face abaxial glabrescente, nervuras esparsamente pubescentes a glabrescentes, glândulas discoides esparsas, nervura principal saliente, as secundárias levemente salientes; face adaxial glabrescente, nervuras glabrescentes, eglandular, nervuras principal a quaternárias levemente salientes; pecíolo 0,5-1 $\mathrm{mm}$ compr.; estípulas lineares a estreitamente triangulares, 2-3,8 mm compr., eglandulares. Inflorescências paniculadas, $1-4 \mathrm{~cm}$ compr., esparsamente pubescentes; brácteas triangulares, 1-3 $\mathrm{mm}$ compr., persistentes, eglandulares; pedicelos 4-6 mm compr., eglandulares; bractéolas triangulares, 1-2 $\mathrm{mm}$ compr., persistentes, eglandulares. Flores 5-7 $\mathrm{mm}$ compr; receptáculo campanulado; sépalas 3,5-4 mm compr., reflexas, margem eglandular; pétalas 4-5 $\mathrm{mm}$ compr., róseas; estames 5, 14-16 mm compr., filetes róseos; estilete 15-16 mm compr., hirsuto apenas na base. Drupas obovoides, 20-22 × 13-15 mm, epicarpo e endocarpo glabros.

Hirtella bicornis ocorre em diversos países da América do Sul e, no Brasil, em quase todos os estados da Região Norte e também em Mato Grosso, Pernambuco (Prance \& Sothers 2003b; Sothers et al. 2016) e Bahia. D7, D9, G8, H8, I8: floresta ombrófila densa e floresta estacional associada a formações rupestres. Coletada com flores de setembro a março e com frutos de novembro a março.

Material selecionado - Entre Rios, RPPN Fazenda Lontra/Saudade, $11^{\circ} 56^{\prime} 31$ "S, 38 $05^{\prime} 04^{\prime \prime W}, 23$ nov. 1997 (fl., fr.), N.G. Jesus et al. 240 (HRB, HUEFS, HUESC); Jacobina, Piemonte da Diamantina, bairro Grotinha, $11^{\circ} 11^{\prime} 45^{\prime \prime S}, 40^{\circ} 30^{\prime} 26^{\prime \prime} \mathrm{W}, 23$ nov. 2001 (fl.), D.L. Santana et al. 625 (ALCB, CEPEC); Porto Seguro, Parque Nacional do Monte Pascoal, 16²6'59"S, 3903'53"W, 5 fev. 1999 (est.), W.W. Thomas et al. 12015 (CEPEC); Santa Cruz Cabrália, Estação Ecológica do Pau Brasil, 16²161"S, 3901'29"W, 3 nov. 1978 (fl.), A. Eupunino 361 (CEPEC); Una, Rebio de Una, trilha da roda d'água, $15^{\circ} 10^{\prime} 18^{\prime \prime} \mathrm{S}, 39^{\circ} 03^{\prime} 40^{\prime \prime} \mathrm{W}, 7 \mathrm{jan}$. 2015 (fl., fr.), R. Asprino et al. 121 (CEPEC); Uruçuca, área do inventário do plano manejo do Parque Estadual da Serra do Conduru, 14'29'59"S, 3906'54"W, abr. 2004 (est.), A. Martini s.n. (CEPEC 122605).

Hirtella bicornis apresenta duas variedades, $H$. bicornis var. bicornis e H. bicornis var. pubescens Ducke, que se diferenciam pelo formato, ápice e base da lâmina foliar, indumento da inflorescência, hábito e hábitat. No presente trabalho, no entanto, optou-se por não adotar as categorias infraespecíficas, visto que é possível perceber uma sobreposição de caracteres, e algumas vezes indivíduos de uma mesma população poderiam se enquadrar em variedades diferentes.

Assemelha-se vegetativamente a $H$. gracilipes (Hook.f.) Prance, pelas lâminas foliares elípticas a oblongas, glabrescentes, com a base obtusa a arredondada e ápice acuminado, e estípulas caducas. Todavia, diferencia-se prontamente pelas inflorescências paniculadas (vs. racemosas) de $1-4 \mathrm{~cm}$ 
compr. (vs. 5-12,5 cm), e por possuir brácteas e bractéolas eglandulares (vs. brácteas e bractéolas com gotículas de secreção translúcida na margem). Este trabalho aponta pela primeira vez a ocorrência de $H$. bicornis no estado da Bahia.

4. Hirtella ciliata Mart. \& Zucc., Abh. Math.-Phys. Cl. Königl. Bayer. Akad. Wiss. 1: 378. 1832.

Figuras 1, 2E-H e 4E-H; Prance \& Sothers (2003b: fig. 70).

Árvores ou arbustos, 1-10 m alt; ramos jovens tomentosos, lenticelados. Folhas com lâmina oblonga a largamente elíptica ou obovada, base obtusa a arredondada ou cuneada, ápice arredondado, mucronado, retuso ou agudo, 3,2-6,8 × 2,5-4,2 cm, cartácea a coriácea, margem plana, 6-9 pares de nervuras secundárias; face abaxial pubescente, nervuras pubescentes, glândulas discoides esparsas, nervuras principal e secundárias salientes; face adaxial esparsamente pubescente, nervuras pubescentes, eglandular, nervura principal saliente, secundárias a quaternárias levemente salientes; pecíolo 0,5-2 mm compr.; estípulas lanceoladas, 34,5 mm compr., eglandulares. Inflorescências paniculadas, 3,5-22 cm compr., esparsamente tomentosas a tomentosas; brácteas estreitamente triangulares a triangulares, 2,5-5 $\mathrm{mm}$ compr., persistentes, glândulas sésseis a curtamente estipitadas na base; pedicelos 1-7 $\mathrm{mm}$ compr., eglandulares; bractéolas deltoides, 1,5-3,5 mm compr., persistentes, glândulas estipitadas em toda a margem. Flores 4-6 mm compr.; receptáculo estreitamente campanulado; sépalas 2,5-3 mm compr., eretas, glândulas na margem; pétalas 3-4 mm compr., brancas; estames 6 ou 7, 8-9 mm compr., filetes róseos a vináceos; estilete ca. $8 \mathrm{~mm}$ compr., hirsuto apenas na base. Drupas elipsoides, $12-15 \times 7-10 \mathrm{~mm}$, epicarpo esparsamente pubescente, endocarpo pubescente.

Hirtella ciliata ocorre na Guiana, Guiana Francesa e, no Brasil, nos estados de Minas Gerais, Goiás, Amapá, Pará, Tocantins e em quase todos os estados da Região Nordeste, incluindo a Bahia (Prance 1972; Prance \& Sothers 2003b; Sothers et al. 2016). B9, C5, C6, C7, C9, D2, D5, D9, D10, E2, E5, E6, E9, E10, F3, F5, G2, G4: cerrado e restinga. Coletada com flores e frutos o ano todo, mais comumente de setembro a fevereiro.

Material selecionado - Alagoinhas, $12^{\circ} 05^{\prime} 47^{\prime \prime} \mathrm{S}, 38^{\circ} 22^{\prime} 06^{\prime \prime} \mathrm{W}$, 23 abr. 2010 (fr.), E. Melo et al. 7933 (HUEFS); Barreiras, caminho para Cachoeira do Acaba Vida, 1209'10"S, 4459'24"W, 17 jul. 1983 (fl.), M.L. Guedes et al. 825 (ALCB); Brotas de Macaúbas, $12^{\circ} 01^{\prime} 12^{\prime \prime S}, 42^{\circ} 43^{\prime} 07^{\prime \prime W}, 2$ ago. 2013 (fr.), D.M. Neves et al. 1541 (HUEFS, RB); Camaçari, condomínio Busca Vida, $12^{\circ} 41^{\prime} 51 " \mathrm{~S}, 38^{\circ} 19^{\prime} 27^{\prime \prime W}$, jan. 2001 (fl.), F.P. Fonseca Neto 51 (HRB); Campo Formoso, Morro do Cruzeiro, 10³0'S, 40²0'W, 31 jan. 1993 (fl., fr.), W.W. Thomas et al. 9664 (CEPEC); Cocos, fazenda Trijunção, área da sede Santa Luzia, 14' $53^{\prime} 26^{\prime \prime S}$, 4552'00"W, 6 jul. 2001 (fl.), M.L. Fonseca et al. 2885 (RB);
Conde, Fazenda do Bu, Mata da Areia Branca, 12 01'34"S, 3701'42"W, 26 out. 1994 (fl.), M.C. Ferreira et al. 636 (CEPEC, HRB, MBM, RB); Coribe, estrada para reflorestamento Desbrava,

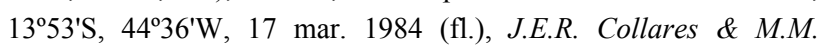
Fernandez 110 (CEPEC, HRB, RB); Correntina, rodovia BA-349, $13^{\circ} 25^{\prime} \mathrm{S}, 44^{\circ} 44^{\prime} \mathrm{W}, 10$ ago. 1996 (fl., fr.), J.G. Jardim et al. 900 (CEPEC); Entre Rios, vale do rio Negro, $12^{\circ} 02^{\prime} \mathrm{S}, 38^{\circ} 01^{\prime \prime} \mathrm{W}, 16$ nov. 2011 (fl.), A.V. Popovkin 963 (HUEFS); Érico Cardoso, Pico das Almas, vertente oeste, $13^{\circ} 31^{\prime} \mathrm{S}, 42^{\circ} 00^{\prime} \mathrm{W}, 17$ dez. 1988 (fr.), R.M. Harley et al. 27586 (CEPEC, MBM, SPF); Esplanada, Baixio, $12^{\circ} 06^{\prime} 47^{\prime \prime S}, 37^{\circ} 41^{\prime} 95^{\prime \prime} \mathrm{W}, 14$ out. 2008 (fl., fr.), E.P. Queiroz 3356 (CEPEC, HRB); Feira de Santana, área do $35^{\circ}$ Batalhão de Infantaria, $12^{\circ} 17^{\prime} 02^{\prime \prime S}, 38^{\circ} 56^{\prime} 13^{\prime \prime} \mathrm{W}, 10$ nov. 2010 (fl.), E. Melo et al. 8706 (HUEFS); Formosa do Rio Preto, estrada para Guaribas, $11^{\circ} 14$ 'S, 452 $25^{\prime} \mathrm{W}, 13$ out. 1994 (fl., fr.), L.P. Queiroz \& N.S. Nascimento 4145 (HUEFS, VIES); Gentio do Ouro, APA de Itaparica, $11^{\circ} 07^{\prime} 38^{\prime \prime S}, 42^{\circ} 44^{\prime} 23^{\prime \prime} \mathrm{W}, 5$ maio 2001 (fl., fr.), M.C. Ferreira et al. 1264 (ALCB, HRB, HUEFS); Inhambupe, fazenda

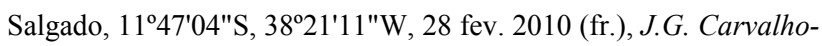
Sobrinho et al. 2708 (HUEFS); Itanagra, Núcleo Agroecológico, 12²2'28"S, 3758'52"W, 1 fev. 2009 (fl., fr.), A.R. Prates et al. 281 (ALCB); Jacobina, Serra do Tombador, $11^{\circ} 09^{\prime} 10^{\prime \prime} \mathrm{S}, 40^{\circ} 29^{\prime} 10^{\prime \prime} \mathrm{W}, 8$ abr. 2001 (fl.), H.P. Bautista et al. 3095 (ALCB, CEPEC, HRB, HUEFS, HUESC); Jandaíra, Abadia, fazenda Areia Branca,

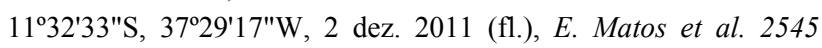
(HUEFS); Jeremoabo, comunidade Baixa dos Quelés, 09 $58^{\circ} \mathrm{S}$, $38^{\circ} 26^{\prime} \mathrm{W}, 12$ dez. 2009 (fl., fr.), V.S. Almeida \& M.S. Barbosa 80 (HUEFS); Lençóis, $2 \mathrm{~km}$ a leste do trevo de Lençóis com a BR-242, $12^{\circ} 29^{\prime} \mathrm{S}, 41^{\circ} 20^{\prime} \mathrm{W}, 2$ ago. 1998 (fl., fr.), J.A. Ratter et al. 8048 (HUEFS, UEC); Luís Eduardo Magalhães, próximo à área residencial, 1205'57"S, 4546'10"W, 20 set. 2003 (fl.), M.L. Guedes et al. 10922 (ALCB); Mata de São João, condomínio particular Quintas de Sauípe, $12^{\circ} 10^{\prime} 00^{\prime \prime S}, 37^{\circ} 47^{\prime} 00^{\prime \prime W}, 10$ jan. 2015 (fl., fr.), L.C. Marinho \& K.M. Pimenta 938 (CEPEC, HUEFS); Nova

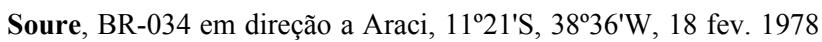
(fl.), R.P. Orlandi 158 (RB); Palmas de Monte Alto, $14^{\circ} 16^{\prime} 02^{\prime \prime} \mathrm{S}$, 4309'43"W, 14 set. 2008 (fl.), E.P. Queiroz 3286 (HRB); Pindobaçu, 1044'30"S, 40²1'39"W, 5 dez. 2003 (fl., fr.), A.M. Miranda et al. 4266 (HUEFS); Ribeira do Pombal, 10 $53^{\prime} 02^{\prime \prime S}$, 38 38'60"W, 24 fev. 2006 (fl., fr.), E. Melo et al. 4263 (HUEFS); Salvador, Veracruz, Aratuba, 12057'S, 38 $36^{\prime} \mathrm{W}, 12$ nov. 1995 (fl., fr.), M.L. Guedes et al. 6603 (ALCB, CEPEC); São Desidério, Palmeiral, 12³1'01"S, 4505'44"W, 16 jun. 2007 (fl.), G. Araújo 161 (HUEFS); São Sebastião do Passé, Lamarão do Passé, ao lado da Caraíba Metais, 12³0'45"S, 38²9'43"W, 8 abr. 2001 (fr.), M.L. Guedes et al. 8308 (ALCB); Saúde, caminho para Cachoeira do Paiaió, 1054'02"S, 40²6'55"W, 4 abr. 1996 (fl., fr.), E. Woodgyer et al. 2841 (ALCB, CEPEC, HRB, HUEFS, SPF); Tucano, estrada para Ribeira do Pombal, 1057'47"S, 3847'12"W, 21 mar. 1992 (fl., fr.), A.M. Carvalho et al. 3917 (CEPEC, HRB, HUEFS, MBM, MBML, RB); Umburanas, Serra do Curral Frio, fazenda Licuri, $10^{\circ} 24^{\prime} 13^{\prime \prime S}, 41^{\circ} 18^{\prime} 42^{\prime \prime} \mathrm{W}, 26$ maio 2010 (fl., fr.), L.P. Queiroz et al. 14842 (HUEFS); Vera Cruz, estrada para Baiacu, 12 $57^{\prime} 37^{\prime \prime S}$, 38³6'31"W, 12 mar. 1995 (fl., fr.), M.L. Guedes \& E. Saar 3659 (ALCB, CEPEC, HRB); Xique-Xique, estrada para Barra, ramal

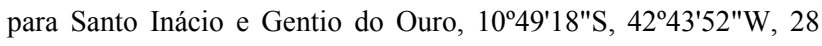
abr. 1999 (fl., fr.), R.C. Forzza et al. 1413 (CEPEC, HUEFS, HUESC, RB, SPF). 


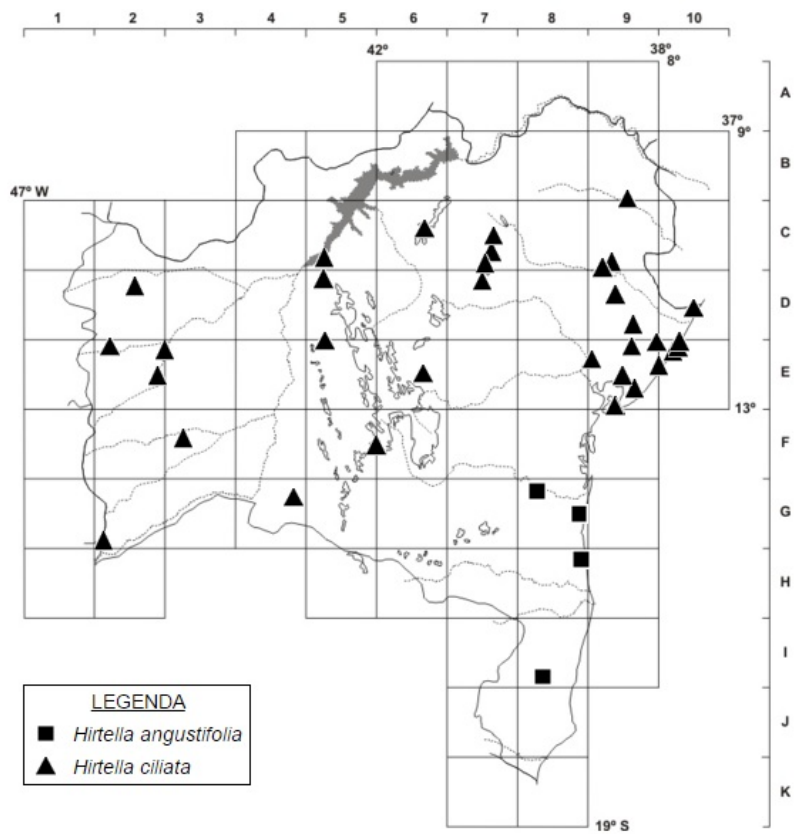

Figura 1. Distribuição geográfica de Hirtella angustifolia e H. ciliata no estado da Bahia.

Hirtella ciliata pode ser reconhecida por apresentar as folhas com pecíolo curto (0,5-2 mm compr.), lâmina foliar frequentemente oblonga a largamente elíptica, face abaxial com indumento pubescente, inflorescências paniculadas com bractéolas deltoides, persistentes, com glândulas estipitadas em toda a margem, e flores com sépalas eretas.

5. Hirtella corymbosa Cham. \& Schltdl., Linnaea, 2: 545. 1827.

Figuras 3 e 4I-J.

Arbustos a subarbustos, 0,3-2 m alt.; ramos jovens pubescentes, lenticelados. Folhas com lâmina elíptica a ovada, base arredondada a subcordada, ápice mucronado, arredondado, agudo ou retuso, 2,8-4,6 $\times$ 2,2-3,4 cm, cartácea, margem plana, 6-8 pares de nervuras secundárias; face abaxial glabrescente, nervuras esparsamente pubescentes, glândulas discoides esparsas, nervura principal saliente, as secundárias levemente salientes; face adaxial glabrescente, nervuras glabrescentes, eglandular, nervuras principal a quaternárias levemente salientes; pecíolo 0,5-1 mm compr.; estípulas lineares, ca. 1,5 $\mathrm{mm}$ compr., eglandulares. Inflorescências corimbosas compostas, 2,5-6,5 cm compr., pubescentes; brácteas triangulares, 1-2,2 $\mathrm{mm}$ compr., persistentes, eglandulares; pedicelos 1-5 mm compr., eglandulares; bractéolas triangulares, 1-1,5 mm compr., persistentes, eglandulares. Flores 4-5 mm compr.; receptáculo estreitamente campanulado; sépalas ca. $2 \mathrm{~mm}$ compr., reflexas, margem eglandular; pétalas ca. $2 \mathrm{~mm}$ compr., brancas; estames 3, ca. $5 \mathrm{~mm}$ compr., filetes brancos; estilete 5-6 mm compr., hirsuto até o $1 / 3$ basal. Drupas obovoides, $16-19 \times$ ca. $11 \mathrm{~mm}$, epicarpo esparsamente pubescente.
Hirtella corymbosa ocorre no litoral do Espírito Santo e no extremo sul da Bahia (Prance \& Sothers 2003b; Sothers et al. 2016). J8, K8: restinga. Coletada com flores em janeiro, abril e de agosto a outubro e com frutos em janeiro, abril e agosto.

Material selecionado - Caravelas, rio do Poço Areinha, 1704'40"S, 39¹8'31"W, 29 ago. 2011 (fl., fr.), E. Matos et al. 481 (HUEFS); Mucuri, $7 \mathrm{~km}$ a noroeste de Mucuri, $18^{\circ} 05^{\prime} 11^{\prime \prime S}$, 39³3'02"W, 14 set. 1978 (fl.), S.A. Mori et al. 10470 (CEPEC, RB); Nova Viçosa, 1753'30"S, 39²2'18"W, 10 abr. 1984 (fl.), G. Hatschbach 47791 (CEPEC, MBM).

Material adicional examinado - BRASIL. ESPÍRITO SANTO: Linhares, Reserva da Vale, 1908'46"S, 39²5'24"W, 35 m s.n.m., 22 jan. 2015 (fl.), A.P.B. Santos et al. 80 (HUEFS).

Hirtella corymbosa pode ser reconhecida por apresentar os ramos conspicuamente lenticelados, pubescentes quando jovens, folhas com pecíolo curto (0,5-1 mm compr.), lâmina elíptica a ovada, dispostas quase paralelamente ao ramo, e inflorescências corimbosas compostas, com brácteas e bractéolas eglandulares. Além disso, as flores possuem pétalas e filetes brancos e apenas três estames curtos (ca. $5 \mathrm{~mm}$ compr).

6. Hirtella glandulosa Spreng., Neue Entdeck. Pflanzenk. 1: 303. 1820.

Figuras 2I-J, 6A-D e 7; Prance \& Sothers (2003b: fig. 70).

Árvores ou arbustos, 1,5-12 m alt; ramos jovens densamente tomentosos, não lenticelados. Folhas com lâmina elíptica a oblonga, base cuneada a arredondada, ápice atenuado a acuminado, $(6,5-) 8,5-15 \times(2,8-) 4,5-$ $8,2 \mathrm{~cm}$, cartácea a coriácea, margem plana a revoluta, 9-13 pares de nervuras secundárias; face abaxial velutina, nervuras velutinas, glândulas discoides esparsas, nervuras principal e secundárias salientes, terciárias e quaternárias levemente salientes; face adaxial glabrescente, nervuras velutinas, glândulas discoides na base, nervura principal saliente, secundárias a quaternárias impressas; pecíolo 3-5 $\mathrm{mm}$ compr.; estípulas estreitamente triangulares, 4,5-8,5 $\mathrm{mm}$ compr., eglandulares. Inflorescências paniculadas, 6-25 cm compr., esparsamente tomentosas a tomentosas; brácteas triangulares, 3-7 mm compr., persistentes, glândulas estipitadas na base e sésseis na margem; pedicelos 1-5 $\mathrm{mm}$ compr., eglandulares; bractéolas oblatas a transversalmente elípticas, 1-2,5 mm compr., persistentes, glândulas estipitadas em toda a superfície. Flores 6-7 $\mathrm{mm}$ compr; receptáculo cilíndrico; sépalas 3-3,5 $\mathrm{mm}$ compr., reflexas, ocasionalmente glândulas na margem; pétalas 4,5-5 mm compr., brancas; estames 5, 11-13 $\mathrm{mm}$ compr., filetes lilás; estilete $12-14 \mathrm{~mm}$ compr., hirsuto até a 1/2 basal. Drupas elipsoides, 12-13 × 77,5 mm, epicarpo glabrescente.

Hirtella glandulosa ocorre na Bolívia, Guiana, Guiana Francesa, Suriname, Venezuela e, no Brasil, em todos os estados da Região Centro-Oeste, e também nos estados de Minas Gerais, Amapá, Amazonas, Pará, 


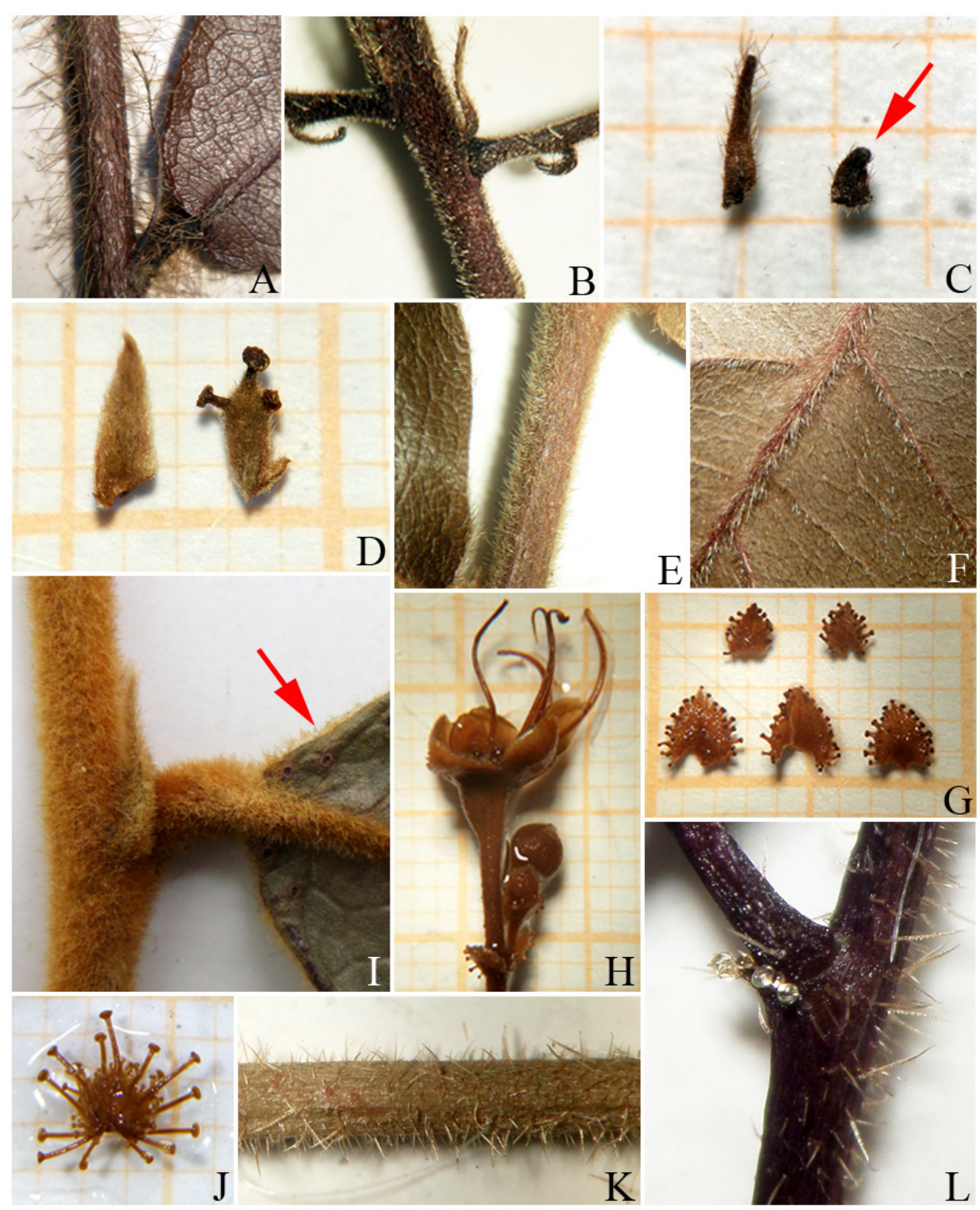

Figura 2. A-C. Hirtella angustifolia: A- detalhe do ramo jovem, pecíolo e estípula; B- detalhe do eixo da inflorescência, pedicelo, bráctea e bractéola; C- bráctea e bractéola com glândula no ápice (seta). D. H. bahiensis: bráctea e bractéola. E-H. H. ciliata: E- detalhe do ramo jovem; F- detalhe da face abaxial da lâmina foliar; G- bractéolas; H- flor passada e botões. I-J. H. glandulosa: I- detalhe do ramo jovem, pecíolo, estípula e base da lâmina foliar com glândulas (seta); J- bractéola. K, L. H. gracilipes: K- detalhe do ramo jovem; L- detalhe do eixo da inflorescência, pedicelo e bractéola. (Fotos: R.C. Asprino).

Bahia, Ceará, Maranhão, Piauí (Prance \& Sothers 2003b; Sothers et al. 2016), Paraíba e Pernambuco (Prance 1972). C6, C7, D2, D5, D6, E2, E5, E6, E7, F3, F5, F6, H8, H9, I8, J8: floresta ciliar em cerrado e campo rupestre, floresta estacional semidecidual e restinga. Coletada com flores e frutos o ano todo, mais comumente de outubro a dezembro.

Material selecionado - Abaíra, Catolés, Serra da Tromba, $13^{\circ} 17^{\prime} 12^{\prime \prime S}, 41^{\circ} 47^{\prime} 32^{\prime \prime W}, 12$ maio 2000 (fl.), E.B. Miranda et al. 490 (HUEFS); Andaraí, BR-142, próximo à ponte sobre o rio Paraguaçu, 120'36"S, 4119'32"W, 1 nov. 2014 (fl., fr.), R.C. Asprino et al. 100 (CEPEC, HUEFS); Barreiras, Rio de Janeiro, próximo à Cachoeira do Acaba Vida, $11^{\circ} 52^{\prime} \mathrm{S}, 45^{\circ} 29^{\prime} \mathrm{W}, 11$ out. 1994 (fl., fr.), L.P. Queiroz \& N.S. Nascimento 4087 (CEPEC, HUEFS, MBM, R); Belmonte, $26 \mathrm{~km}$ ao sul da cidade, 15 $51^{\prime} 47^{\prime \prime S}$,
38 52'58"W, 7 jan. 1981 (fl., fr.), A.M. Carvalho \& J. Gatti 469 (CEPEC, HRB, HUEFS, MBM); Brotas de Macaúbas, Santa

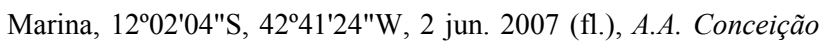
2160 (HUEFS); Camacan, estrada Camacan-Canavieiras, 15²5'09"S, 39 25'45"W, 22 jan. 1971 (fl., fr.), T.S. Santos 1402 (CEPEC, RB); Campo Formoso, Delfino, fazenda Riachão, $10^{\circ} 30^{\prime} 27^{\prime \prime S}, 40^{\circ} 19^{\prime} 17^{\prime \prime W}, 4$ set. 1972 (fl.), F.B. Ramalho 145 (HUEFS); Canavieiras, estrada Santa Luzia-Canavieiras Km 22, 1540'30"S, 38 56'50"W, 27 abr. 1972 (fl., fr.), T.S. Santos 2287 (CEPEC); Caravelas, Cardoso-Treme, 1747'59"S, 39²3'22"W, 16 dez. 2011 (fl., fr.), E. Matos et al. 997 (HUEFS); Caturama, entre Caieiras e Tambori, 13¹5'16"S, 42 $12^{\prime} 32^{\prime \prime} \mathrm{W}, 4$ jul. 2007 (est.), A.A. Conceição et al. 2378 (HUEFS); Correntina, margem do rio

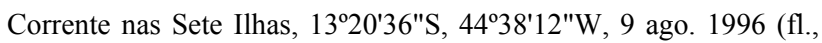
fr.), J.G. Jardim et al. 882 (ALCB, CEPEC, HRB, HUEFS, MBM); 


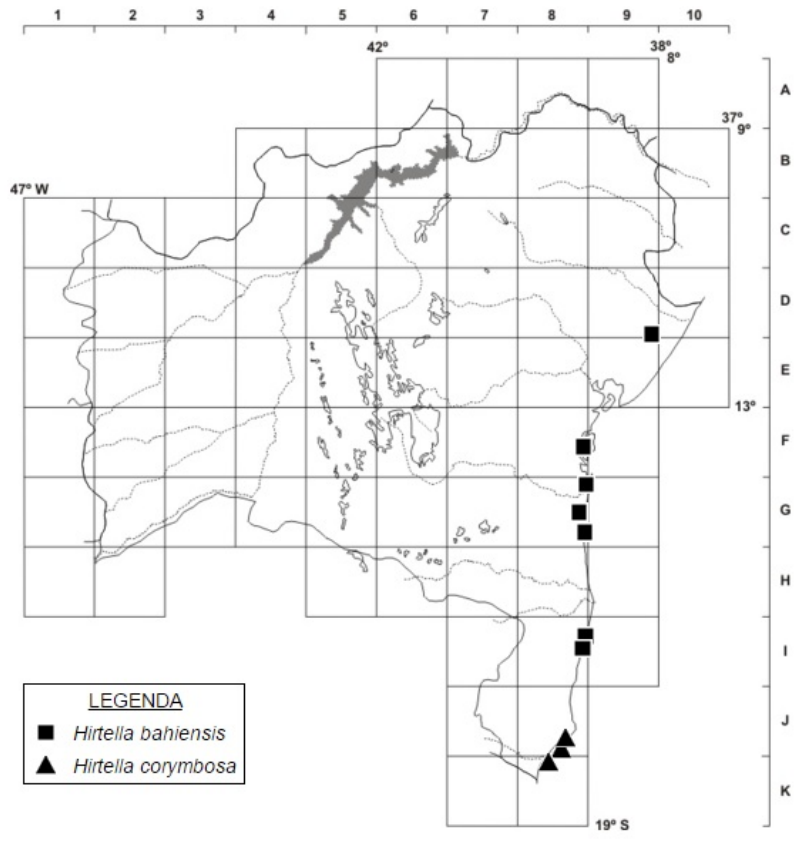

Figura 3. Distribuição geográfica de Hirtella bahiensis e H. corymbosa no estado da Bahia.

Érico Cardoso, Capão, estrada Porteira em direção a Vereda,

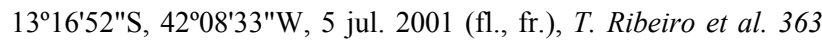
(ALCB, CEPEC, HRB, HUEFS, HUESC); Gentio do Ouro, Santo Inácio, Encantado, $11^{\circ} 05^{\prime} 48^{\prime S}$, 42 43'18"W, 20 jul. 2000 (fl., fr.), M.M. da Silva 480 (HUEFS); Iaçu, às margens do rio Paraguaçu, $12^{\circ} 46$ 'S, 40¹3'W, 24 nov. 2001 (fl.), A.T. Silva s.n. (HUEFS 58627); Ibicoara, caminho para a Cachoeira do Buracão,

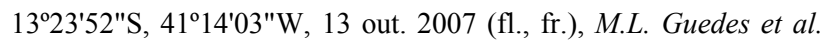
13780 (ALCB); Itaberaba, Serra do Orobó, fazenda Monte Verde, 12³1'39"S, 40¹8'25"W, 13 nov. 1983 (fl.), H.P. Bautista 1324 (ALCB, CEPEC, HRB, MBM, RB); Itaetê, assentamento Baixão, próximo ao rio Una, 12 $59^{\prime} 11^{\prime \prime S}, 40^{\circ} 58^{\prime} 21 " \mathrm{~W}, 13$ abr. 2001 (fl.), D.M. Loureiro et al. 97 (ALCB, CEPEC); Ituaçu, 13\%48'48"S, 41 $17^{\circ} 48^{\prime \prime W}, 27$ nov. 1988 (fl.), E. Gouvea 3/88 (ALCB);

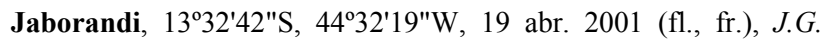
Jardim et al. 3707 (CEPEC, HUESC, HUEFS, RB); Lençóis, ca. 2 $\mathrm{km}$ ao norte da saída da cidade, em direção à BR-242, 12³3'48"S, 4122'36"W, 26 out. 2014 (fl.), L.P. Queiroz et al. 16034 (HUEFS); Livramento de Nossa Senhora, rodovia Livramento-Rio de Contas

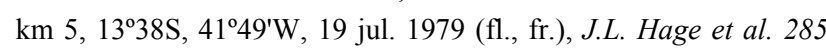
(CEPEC); Morro do Chapéu, estrada para Lagoa Nova,

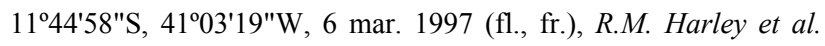
6094 (ALCB, CEPEC, HRB, HUEFS, SPF); Palmeiras, Pai Inácio,

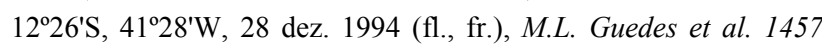
(ALCB, CEPEC, HUEFS, RB); Paramirim, 13ำ $17^{\prime} 13^{\prime \prime S}$, 42 $12^{\prime} 17 " \mathrm{~W}, 29$ abr. 2007 (est.), A.A. Conceição 2019 (HUEFS); Piatã, estrada Piatã-Abaíra, entroncamento para Catolés,

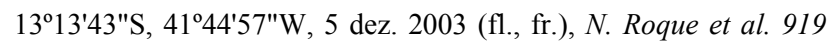
(ALCB); Porto Seguro, estrada Arraial D'Ajuda-Trancoso, 1626'59"S, 3903'53"W, 12 dez. 1991 (fl., fr.), S.C. Sant'Ana et al. 82 (CEPEC, HUEFS, MBM, RB); Rio de Contas, margem do rio

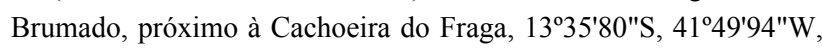
28 out. 2014 (fl.), R.C. Asprino et al. 86 (CEPEC, HUEFS); Ruy Barbosa, Serra do Orobó, estrada para o Riacho da Prata, $12^{\circ} 18^{\prime} 38^{\prime \prime} \mathrm{S}, 40^{\circ} 29^{\prime} 30^{\prime \prime} \mathrm{W}, 17 \mathrm{dez} .2004$ (fl., fr.), L.P. Queiroz et al.
9858 (HUEFS); Santa Cruz Cabrália, ramal para a fazenda Aida Hartman, 16² 16'41"S, 3901'29"W, 14 out. 1983 (fl.), G. Martnelli \& T. Soderstrom 9649 (CEPEC, RB); São Desidério, Manoel de Souza, 12³1'08"S, 4505'56"W, 21 jul. 2007 (fl.), A. Cotrim et al. 1144 (HUEFS); Umburanas, borda do rio Murim, 10 $30^{\prime} 21$ "S, $41^{\circ} 19^{\prime} 53^{\prime \prime W}, 20$ set. 2008 (fl.), E. Melo et al. 5986 (HUEFS); Utinga, entrada $9 \mathrm{~km}$ a noroeste de Utinga na BA-046, $12^{\circ} 01^{\prime} \mathrm{S}$, $41^{\circ} 02^{\prime} \mathrm{W}, 17$ out. 1994 (fl.), L.P. de Queiroz \& N.S. Nascimento 4217 (HUEFS); Wagner, entre as fazendas Bonito e Bonito do Meio, $12^{\circ} 15^{\prime} \mathrm{S}, 41^{\circ} 14^{\prime} \mathrm{W}, 9$ abr. 1986 (est.), A.C. Sarmento \& H.P. Bautista 884 (HRB).

Hirtella glandulosa pode ser caracterizada por apresentar os ramos jovens densamente tomentosos, folhas velutinas na face abaxial e com glândulas discoides facilmente visíveis na base da lâmina na face adaxial e inflorescências paniculadas com brácteas e bractéolas com muitas glândulas estipitadas. Na época de floração, as glândulas nas brácteas e bractéolas liberam uma secreção, conferindo viscosidade peculiar às inflorescências.

7. Hirtella gracilipes (Hook.f.) Prance, F1. Neotrop. Monogr. 9: 323. 1972.

Figuras $2 \mathrm{~K}-\mathrm{L}, 5$ e $6 \mathrm{I}-\mathrm{J}$.

Árvores ou arbustos, 1-8 $\mathrm{m}$ alt; ramos jovens esparsamente pubescentes a glabrescentes, não lenticelados. Folhas com lâmina elíptica a oblonga ou ovada, base obtusa a arredondada, ápice atenuado a acuminado, 6-10,2 × 2,5-4,4 cm, cartácea, margem plana, 6-9 pares de nervuras secundárias; face abaxial glabrescente, nervuras esparsamente pubescentes, glândulas discoides esparsas, nervuras principal e secundárias levemente salientes; face adaxial glabrescente, nervuras glabrescentes, eglandular, nervuras principal e secundárias levemente salientes; pecíolo 1-2 mm compr.; estípulas lanceoladas, 5-6 $\mathrm{mm}$ compr., ocasionalmente glândulas na margem. Inflorescências racemosas, 5-12,5 cm compr., esparsamente pubescentes; brácteas estreitamente triangulares a triangulares, 1,5-2 mm compr., caducas, gotículas de secreção translúcida na margem; pedicelos 7-15 mm compr., eglandulares; bractéolas largamente ovadas, 0,5-1,5 mm compr., caducas, gotículas de secreção translúcida na margem. Flores $6,5-8 \mathrm{~mm}$ compr; receptáculo estreitamente campanulado; sépalas ca. $5 \mathrm{~mm}$ compr., reflexas, gotículas de secreção translúcida na margem; pétalas 5-6 $\mathrm{mm}$ compr., brancas, às vezes com ápice lilás; estames 6, 11-14 mm compr., filetes lilás; estilete 11-12 mm compr., hirsuto até a 1/2 basal. Drupas elipsoides, 18-20 × 12$13 \mathrm{~mm}$, epicarpo glabrescente, endocarpo glabro.

Hirtella gracilipes ocorre na Bolívia, Equador, Peru e, no Brasil, em todos os estados da Região CentroOeste e também nos estados do Pará, Rondônia, Tocantins, Minas Gerais, Rio de Janeiro, São Paulo, Piauí e Bahia (Prance \& Sothers 2003b; Sothers et al. 2016). D2, D3, E3, E8, F3, G3, G4: floresta ciliar em cerrado e floresta estacional. Coletada com flores de março a novembro, e com frutos de julho a outubro. 


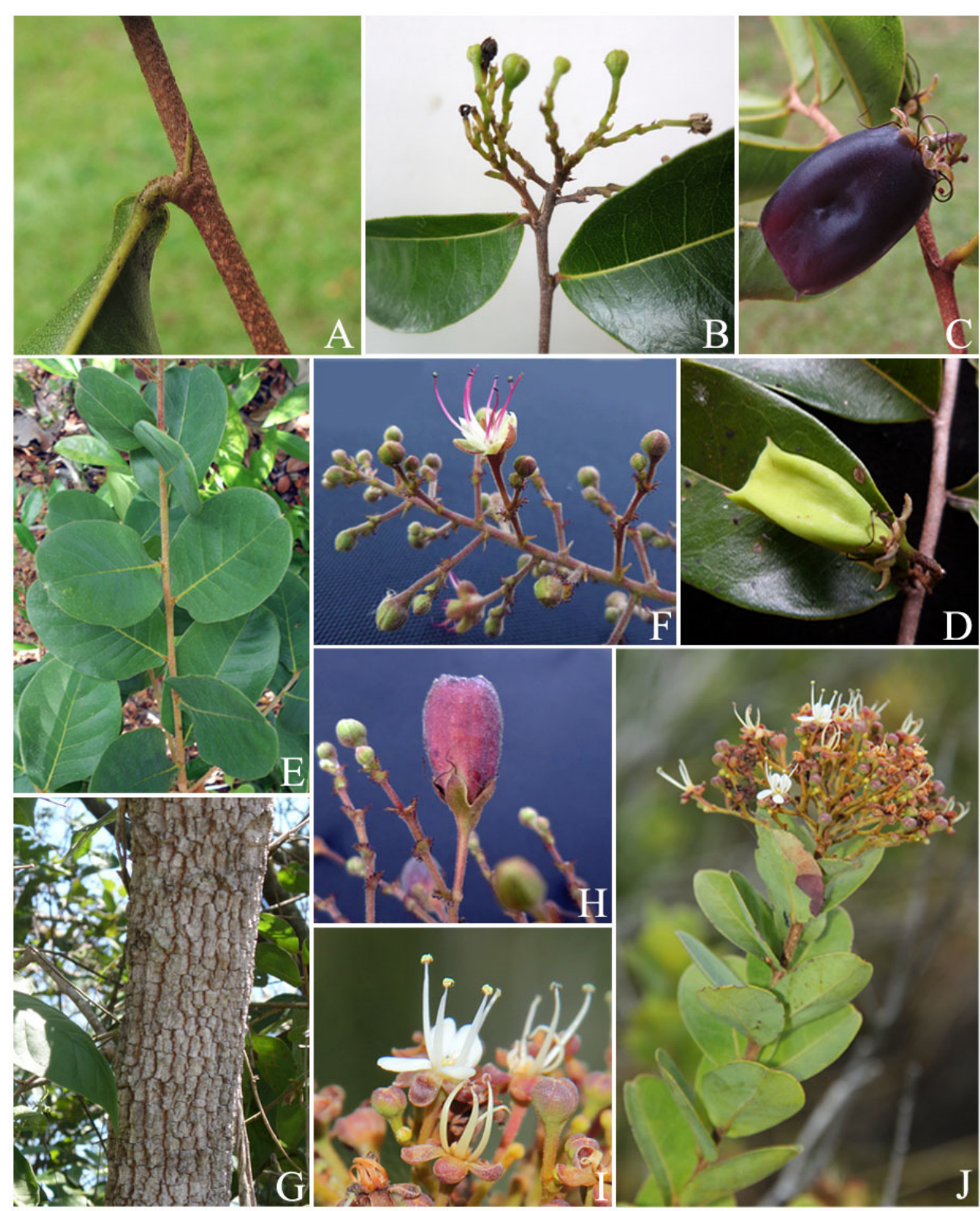

Figura 4. A-D Hirtella bicornis: A- detalhe do ramo e estípula; B- inflorescência com botões e flor passada; C- fruto maduro, vista lateral; D- fruto imaturo, vista lateral. E-H. H. ciliata: E- ramo com folhas em face adaxial; F- detalhe da inflorescência com botões e flor em antese; G- detalhe do tronco; H- fruto imaturo, vista lateral. I-J. H. corymbosa: I- detalhe da inflorescência com botão, flor em antese e flores passadas; J- ramo com folhas e inflorescência. (Fotos: A, C, D- O.L.M. Silva; B, F-H- R.C. Asprino; E- L.C Marinho; I, J- F.S. Espírito-Santo).

Material selecionado - Cachoeira, Ilha do Umbuzeiro, 12²3'S, 3905'W, ago. 1980 (fl., fr.), Grupo Pedra do Cavalo 612 (ALCB, CEPEC, HRB, RB, UEC); Carinhanha, médio São Francisco, $14^{\circ} 18^{\prime} \mathrm{S}, 43^{\circ} 45^{\prime} \mathrm{W}, 26$ maio 2007 (fl.), M.L. Guedes et al. 14143 (ALCB, HUEFS); Cocos, ca. $24 \mathrm{~km}$ a oeste de Cocos, Tamanduá, $14^{\circ} 17^{\prime} 18^{\prime \prime} \mathrm{S}, 4^{\circ} 43^{\prime} 02^{\prime \prime W}, 16$ maio 2001 (fl.), F. França et al. 3612 (ALCB, CEPEC, HUEFS, HRB); Correntina, margem do rio Corrente, $13^{\circ} 20^{\prime} 45^{\prime \prime} \mathrm{S}, 44^{\circ} 38^{\prime} 41^{\prime \prime} \mathrm{W}, 30$ out. 2014 (fl., fr.), R.C. Asprino et al. 88 (HUEFS); Feira da Mata, médio São Francisco, próximo ao rio Carinhanha, $14^{\circ} 13^{\prime} 54^{\prime \prime} \mathrm{S}, 44^{\circ} 12^{\prime} 45^{\prime \prime} \mathrm{W}, 6$ maio 2007 (fl.), M.L. Guedes et al. 13405 (ALCB, HUEFS, MBM); Formosa

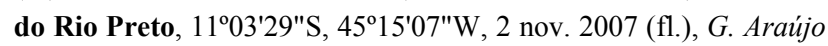

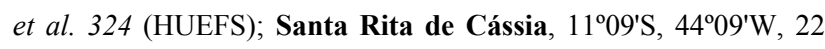
ago. 1980 (fl.), Santino 284 (HRB, MBM, RB); São Desidério, BR-
135 de Correntina para Barreiras, $12^{\circ} 25^{\prime} 04^{\prime \prime} \mathrm{S}, 4^{\circ} 47^{\prime} 56^{\prime \prime} \mathrm{W}, 30$ out. 2014 (fl., fr.), R.C. Asprino et al. 89 (HUEFS).

Hirtella gracilipes assemelha-se a $H$. racemosa Lam. pelos ramos jovens e inflorescências com indumento do tipo pubescente, lâminas foliares geralmente oblongas ou ovadas, com 6-9 pares de nervuras secundárias, inflorescências racemosas e flores com 5 ou 6 estames. Todavia, distingue-se por apresentar indumento menos denso nos ramos jovens e inflorescências (esparsamente pubescente a glabrescente vs. pubescente), lâminas foliares com ápice geralmente acuminado (vs. agudo a atenuado), pedicelos mais longos (7-15 $\mathrm{mm}$ vs. $3-11 \mathrm{~mm}$ compr.), brácteas e bractéolas caracteristicamente com 


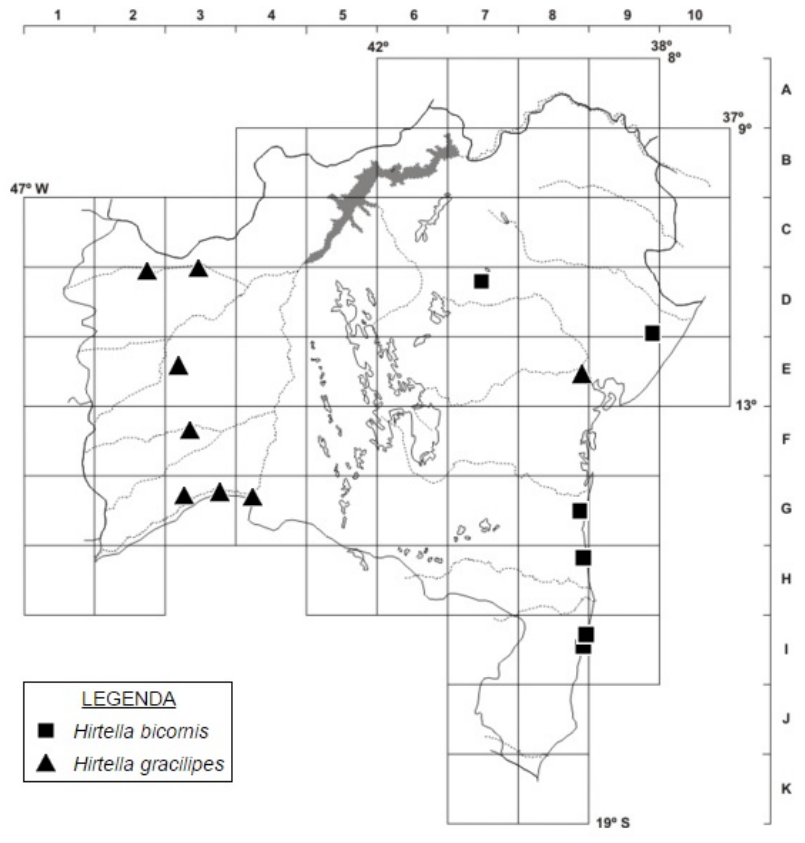

Figura 5. Distribuição geográfica de Hirtella bicornis e H. gracilipes no estado da Bahia.

gotículas de secreção translúcida na margem (vs. com ou sem glândulas, mas nunca com gotículas de secreção translúcida), além de flores com receptáculo estreitamente campanulado (vs. cilíndrico). Em algumas amostras, é nítida a presença de glândulas diminutas na margem das estípulas, mas essa caraterística não foi mencionada por Prance (1972, 1988, 2003) em suas descrições da espécie. Vegetativamente, assemelha-se também a $H$. bicornis; as semelhanças e diferenças entre essas espécies são apresentadas nos comentários de H. bicornis.

8. Hirtella insignis Briq. ex Prance, Fl. Neotrop. Monogr. 9: 279. 1972.

Figuras 8 e 9A, B; Prance (1972: fig. 45).

Árvores, 5-15 m alt.; ramos jovens esparsamente hirsutos a glabrescentes, lenticelados. Folhas com lâmina elíptica a largamente elíptica ou oblonga, base subcordada, arredondada ou cuneada, ápice atenuado a acuminado, 6,5-19,2 × 4,4-9,7 cm, cartácea, margem plana a levemente revoluta, 6-10 pares de nervuras secundárias; face abaxial glabrescente, nervuras glabrescentes, glândulas discoides na base e no ápice, nervura principal saliente, as secundárias levemente salientes; face adaxial glabrescente, nervuras glabrescentes, eglandular, nervuras principal e secundárias levemente salientes; pecíolo 1-5 $\mathrm{mm}$ compr.; estípulas lineares, 4,5-5,5 $\mathrm{mm}$ compr., eglandulares. Inflorescências corimbosas compostas, 4-7 cm compr., esparsamente hirsutas; brácteas oblongas, 2,5-3,2 mm compr., caducas, glândula longamente estipitada no ápice; pedicelos 4-8 $\mathrm{mm}$ compr., eglandulares; bractéolas oblongas, 1,5-2,5 mm compr., caducas, glândula longamente estipitada no ápice. Flores 5,5-6,5 $\mathrm{mm}$ compr.; receptáculo campanulado; sépalas 4-4,5 $\mathrm{mm}$ compr., reflexas, margem eglandular; pétalas $4-5 \mathrm{~mm}$ compr., brancas; estames 5, 11-12 mm compr., filetes lilás; estilete 12$13 \mathrm{~mm}$ compr., hirsuto até o $1 / 3$ basal. Drupas obovoides, 19-20 × 9-10 mm, epicarpo glabro.

Hirtella insignis ocorre no litoral dos estados da Bahia e do Espírito Santo (Prance \& Sothers 2003b; Sothers et al. 2016). E9, F8, G8, H8, I8, J8: floresta ombrófila densa, floresta de tabuleiro e restinga. Coletada com flores de janeiro a julho e novembro, e com frutos em abril.

Material selecionado - Camacan, BR-101 ao rio Pardo, 1525'09"S, 39²9'45"W, 24 maio 1971 (fl.), T.S. Santos 1695 (CEPEC); Ilhéus, rodovia Ilhéus-Olivença, fazenda Manguinho, 14 $55^{\prime} \mathrm{S}, 39^{\circ} 05^{\prime} \mathrm{W}, 30$ jan. 1994 (fl.), W.W. Thomas et al. 10212 (CEPEC, HRB, MBM); Itacaré, fazenda Patizeiro, 14'23'25"S, 3901'56"W, 15 abr. 2006 (fl.), C.M. Menezes 397 (HRB); Porto Seguro, RPPN Estação Veracruz, 16²5'09"S, 39²12'08"W, 2 jul. 2006 (fl.), M.M.M. Lopes et al. 945 (CEPEC); Prado, fazenda

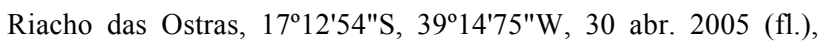
S.G. Rezende \& A.E. Brina 1657 (HUEFS); Salvador, Jardim Botânico de Salvador, 1255'37"S, 38²5'37"W, 12 fev. 2004 (fl.), E.P. Queiroz 371 (HRB); Santa Cruz Cabrália, Estação Ecológica do Pau Brasil, 16²16'41"S, 3901'29"W, 26 nov. 1987 (f1.), P.J.M. Maas et al. 7039 (CEPEC); Una, fazenda Bolandeira, $15^{\circ} 20^{\prime} 24^{\prime \prime S}, 39^{\circ} 00^{\prime} 28^{\prime \prime} \mathrm{W}, 21$ abr. 2012 (fl., fr.), E. Matos \& M. Fernandes 3389 (HUEFS); Uruçuca, fazenda Lagoa do Conjunto Fazenda Santa Cruz, 14²5'S, 3901'"W, 1 jul. 1991 (est.), W.W. Thomas et al. 7194 (CEPEC); Valença, rodovia Valença-Guaibim Km 10, 1322'13"S, 3904'23"W, 22 fev. 1975 (fl.), T.S. Santos 2898 (CEPEC, RB).

Hirtella insignis pode ser reconhecida dentre as espécies na Bahia por apresentar ramos conspicuamente lenticelados, com indumento esparsamente hirsuto a glabrescente, lâminas foliares glabrescentes em ambas as faces, tornando-se marrons quando herborizadas, além de inflorescências corimbosas compostas, com brácteas e bractéolas oblongas que possuem uma glândula longamente estipitada no ápice.

9. Hirtella martiana Hook.f., Fl. Bras. 14(2): 29. 1867.

Figuras 8, 9C-E e 10A-E; Prance \& Sothers (2003b: fig. 70).

Árvores ou arvoretas, 3-10 m alt.; ramos jovens com indumento lanoso sobre indumento esparsamente pubescente, não lenticelados. Folhas com lâmina oblonga a estreitamente oblonga, base obtusa a arredondada ou cuneada, ápice agudo a atenuado ou acuminado, 7-10 × 2,3-4,5 cm, cartácea a coriácea, margem plana a levemente revoluta, 7-10 pares de nervuras secundárias; face abaxial glabrescente, nervuras glabrescentes, glândulas discoides na base e no ápice, nervura principal saliente; face adaxial glabrescente, nervuras glabrescentes, eglandular, nervuras principal e secundárias levemente salientes; 
pecíolo 3-5 mm compr.; estípulas lanceoladas, 3,5-5,5 mm compr., ocasionalmente glândulas na margem. Inflorescências racemosas, 3-12,5 cm compr., indumento lanoso sobre indumento pubescente; brácteas estreitamente triangulares a triangulares, 4,5-5,5 $\mathrm{mm}$ compr., persistentes, glândulas sésseis em toda a margem; pedicelos 7-11 $\mathrm{mm}$ compr., eglandulares; bractéolas triangulares, ca. $2 \mathrm{~mm}$ compr., persistentes, glândulas sésseis a curtamente estipitadas em toda a margem. Flores $8,5-10 \mathrm{~mm}$ compr., receptáculo cilíndrico; sépalas 5-6 mm compr., reflexas, glândulas na margem; pétalas 4-5 mm compr., brancas; estames 8 , 14-15 mm compr., filetes brancos; estilete ca. $16 \mathrm{~mm}$ compr., hirsuto até $2 / 3$ basais. Drupas elipsoides, 18-19 $\times$ 11-12 mm, epicarpo densamente pubescente, endocarpo densamente tomentoso.
Hirtella martiana ocorre nos estados de Goiás, Distrito Federal, Minas Gerais e Bahia (Prance \& Sothers 2003b; Sothers et al. 2016). Sua ocorrência também foi apontada para o Espírito Santo (Prance \& Sothers 2003b; Sothers et al. 2016), mas constatamos que essa informação está baseada em espécimes de $H$. parviunguis Prance erroneamente identificados. F5, F6, G3, G5: floresta ciliar em cerrado e campo rupestre. Coletada com flores de junho a outubro e com frutos de junho a novembro.

Material selecionado - Abaíra, estrada de Catolés para Abaíra, $13^{\circ} 17^{\prime} \mathrm{S}, 41^{\circ} 48^{\prime} \mathrm{W}, 7$ set. 1996 (fl., fr.), R.M. Harley et al. 28351 (HRB, HUEFS, R, VIES); Caetité, fazenda Ouriçangas, $14^{\circ} 04^{\prime} 10^{\prime \prime S}$, 42²8'30"W, 19 set. 2003 (fl., fr.), A.M. Miranda et al. 4187 (HUEFS); Caturama, entre Candeias e Tambori, $13^{\circ} 15^{\prime} 16^{\prime \prime S}$, 42 $12^{\prime} 32^{\prime \prime W, ~} 4$ jul. 2007 (fl., fr.), A.A. Conceição et al. 2354

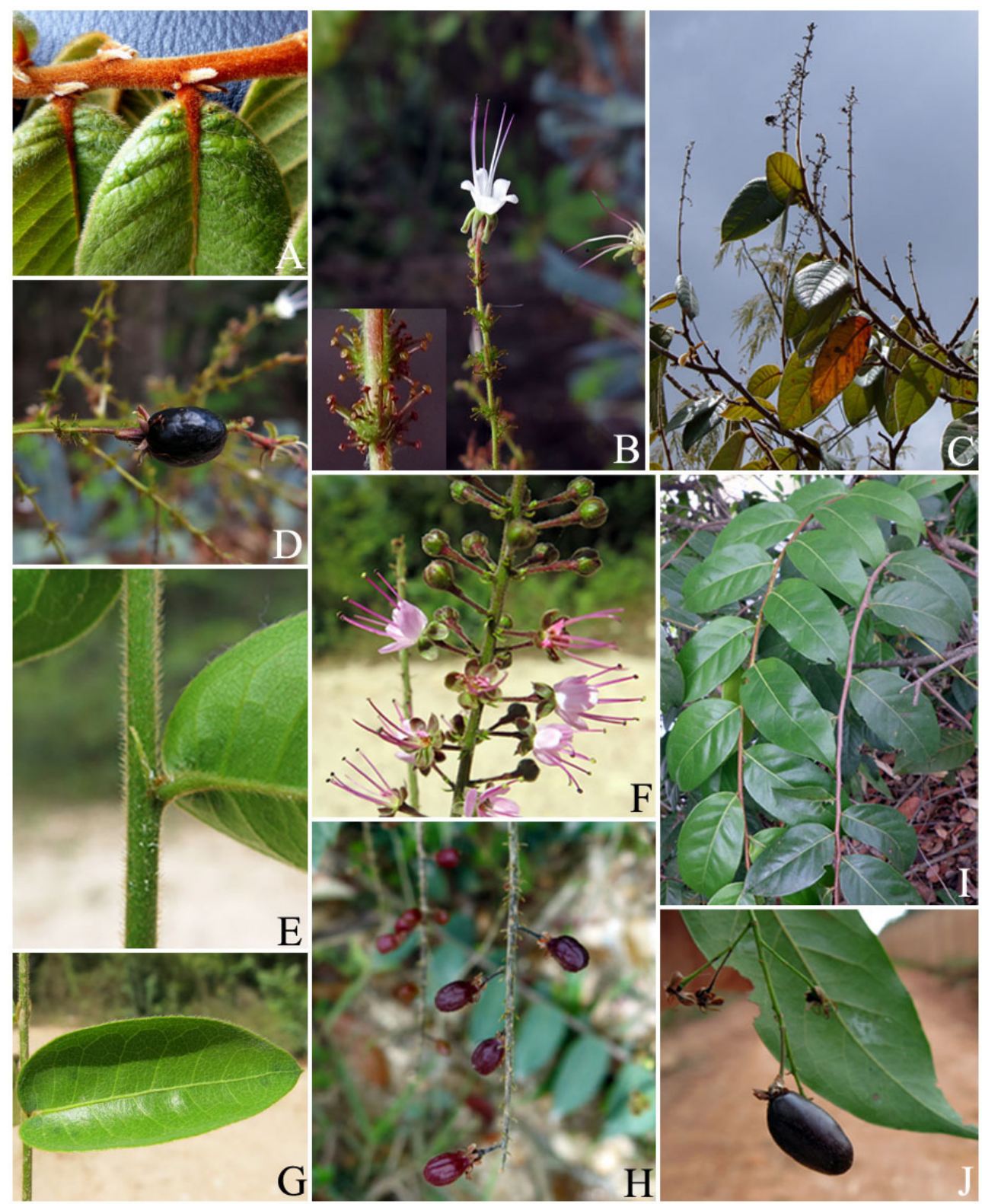

Figura 6. A-D. Hirtella glandulosa: A- detalhe do ramo, estípulas e lâmina foliar em face adaxial com glândulas basais; B- detalhe da inflorescência com flor em antese e bractéolas com glândulas estipitadas; C- ramos com folhas e inflorescências; D- fruto maduro, vista lateral. E-H. H. racemosa: E- detalhe do ramo e estípula; F- detalhe da inflorescência com botões e flores em antese; G- lâmina foliar, face adaxial; H- frutos maduros. I, J. H. gracilipes: I- detalhe dos ramos pendentes com folhas em face adaxial; J- fruto maduro, vista lateral. (Fotos A, C, I- R.C. Asprino; B, D, J- M. Alves; E-H- R.F. Almeida). 
(ALCB, HUEFS); Cocos, fazenda Capitão da Mata, 14²3'15"S, 44³3'13"W, 18 jul. 2007 (fl.), M.L. Guedes \& M.L. Valadão 13635 p.p. (ALCB, HUEFS, MBM); Érico Cardoso, Porteira, estrada para

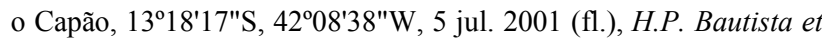
al. 3302 (ALCB, CEPEC, HRB, HUEFS, HUESC); Lagoa Real, fazenda Boa Vista, $14^{\circ} 02^{\prime} 05^{\prime \prime S}, 42^{\circ} 08^{\prime} 32^{\prime \prime} \mathrm{W}, 10$ out. 2002 (fl.), E.C. Santos 20 (MBM); Paramirim, fazenda Jambeiro, 13²6'33"S, 42¹4'20"W, 14 jul. 1972 (fl.), F.B. Ramalho 124 (HUEFS); Rio de Contas, margem do rio Brumado, próximo à Cachoeira do Fraga,

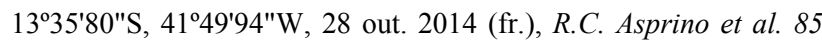
(CEPEC, HUEFS).

Hirtella martiana pode ser reconhecida por apresentar ramos, pecíolos e inflorescências lanosos quando jovens, inflorescências racemosas com brácteas e bractéolas que persistem até a maturação do fruto e possuem glândulas sésseis na margem, flores com receptáculo cilíndrico, pétalas e filetes brancos, e frutos com epicarpo densamente pubescente. É a única espécie de Hirtella na Bahia que apresenta indumento lanoso nos ramos, pecíolo, folhas e inflorescências quando jovens. Em algumas amostras, são observadas diminutas glândulas na margem das estípulas, característica que não foi mencionada por Prance (1972, 1988).

10. Hirtella prancei Asprino \& Amorim, Phytotaxa 265(3): 260. 2016.

Figuras 7 e $12 \mathrm{~A}-\mathrm{E}$.

Árvores ou arvoretas, 3-15 m alt.; ramos jovens densamente velutinos, não lenticelados. Folhas com lâmina largamente elíptica a ovada, base obtusa a arredondada ou subcordada, ápice agudo a atenuado ou acuminado, $17,5-32,5 \times 10,3-18 \mathrm{~cm}$, cartácea a coriácea, margem revoluta, 13-16 pares de nervuras secundárias; face abaxial esparsamente velutina, nervuras esparsamente velutinas, eglandular, nervuras

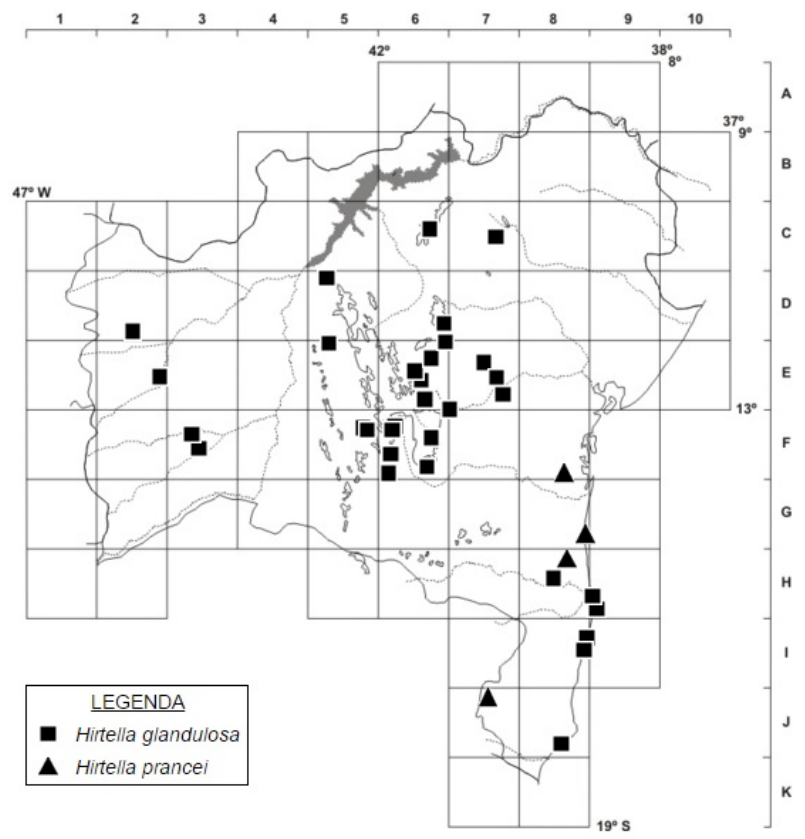

Figura 7. Distribuição geográfica de Hirtella glandulosa e H. prancei no estado da Bahia. principal a quaternárias salientes; face adaxial glabrescente, nervuras glabrescentes, eglandular, nervura principal plana, secundárias a quaternárias impressas; pecíolo 6-10 $\mathrm{mm}$ compr.; estípulas estreitamente triangulares, 6-10 $\mathrm{mm}$ compr., eglandulares. Inflorescências racemosas, $18-40 \mathrm{~cm}$ compr., densamente velutinas; brácteas estreitamente triangulares a triangulares, $(1,5-) 2-4,5(-6) \mathrm{mm}$ compr., caducas, eglandulares; pedicelos 5,5-12 $\mathrm{mm}$ compr., eglandulares; bractéolas triangulares a deltóides, 1-3 mm compr., caducas, eglandulares. Flores 7-10 mm compr.; receptáculo campanulado; sépalas 6-7 $\mathrm{mm}$ compr., eretas, margem eglandular; pétalas 5,5-6,5 mm compr., róseas; estames 6-8, 19,522,5 mm compr.; estilete 22-24 mm compr., hirsuto até o 1/4 basal. Drupas obovoides, 25-36 × 15-20 $\mathrm{mm}$, epicarpo esparsamente pubescente a glabrescente.

Hirtella prancei foi registrada apenas no estado da Bahia (Asprino \& Amorim 2016). F8, G8, H8, J7: floresta ombrófila densa. Coletada com flores em março e dezembro e com frutos em abril.

Material selecionado - Arataca, Parque Nacional da Serra das Lontras, 150'ㄹ' S, 39018'36"W, 16 dez. 2014 (fl.), R. Asprino \& A.M. Amorim 117 (holótipo CEPEC, isótipos HUEFS, K, RB); ib., 5 abr. 2014 (fr.), R. Asprino et al. 61 (parátipo CEPEC); Igrapiúna, assentamento Mirante, 135' $20^{\prime \prime} \mathrm{S}, 39^{\circ} 20^{\prime} 59^{\prime \prime W}, 18 \mathrm{dez} .2001$ (fl.), D.M. Loureiro et al. 394 (parátipos ALCB, CEPEC); Ilhéus, fazenda Attalea, distrito de Castelo Novo, 14 47'20"S, 39 $02^{\prime} 57^{\prime \prime} \mathrm{W}$, 3 mar. 1995 (fl.), L.A. Mattos-Silva 3074 (parátipo CEPEC); Itanhém, estrada de Itanhém a Batinga, fazenda Pedra Grande,

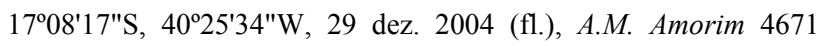
(CEPEC, MBM, RB, SPF).

Hirtella prancei é endêmica da Bahia, descrita a partir do desenvolvimento deste trabalho. Assemelhase a $H$. santosii Prance pelo indumento denso nos ramos jovens e inflorescências, tornando-se castanho

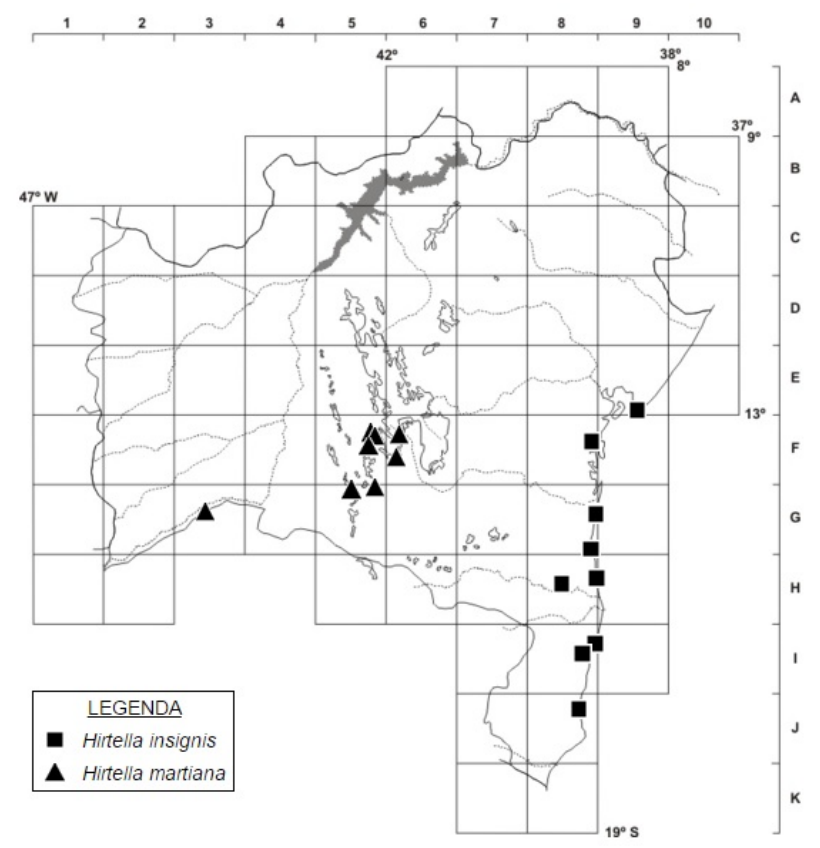

Figura 8. Distribuição geográfica de Hirtella insignis e H. martiana no estado da Bahia. 


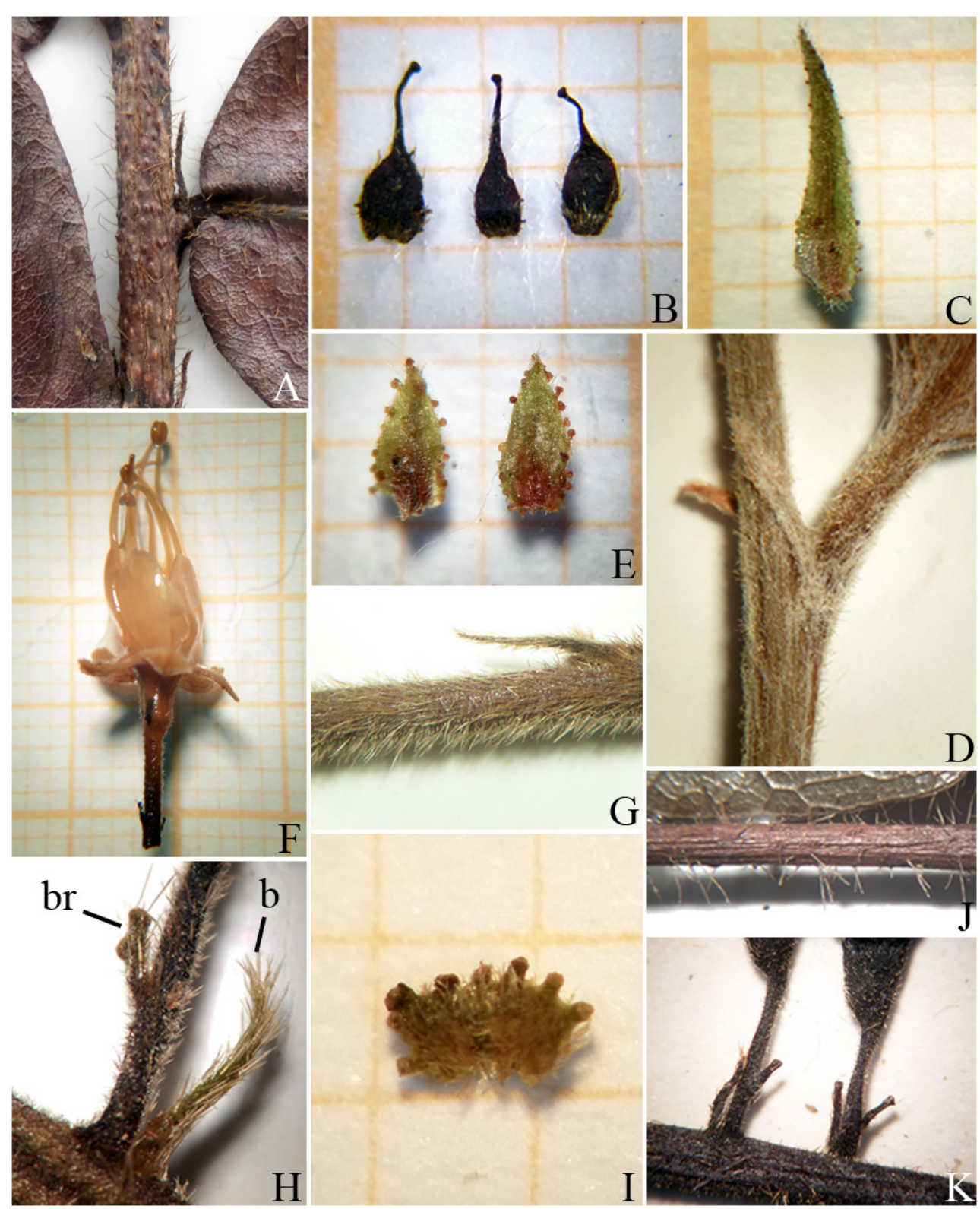

Figura 9. A, B. Hirtella insignis: A- detalhe do ramo jovem, pecíolo e estípula; B- bractéolas. C-E. H. martiana: C- estípula; D- detalhe do ramo jovem, pecíolo e estípula; E- bractéolas. F-H. H. racemosa: F- flor em antese, vista lateral; G- detalhe do ramo jovem e estípula; H- detalhe do pedicelo, bráctea (b) e bractéola (br). I. H. santosii: bractéola. J, K. H. sprucei: J- detalhe do ramo jovem; K- detalhe da inflorescência com pedicelos, bráctea e glândulas estipitadas. (Fotos: R.C. Asprino).

amarelados quando secos, inflorescências racemosas, e flores com 6-10 $\mathrm{mm}$ de comprimento. Diferencia-se principalmente pelo indumento dos ramos jovens, pecíolo e inflorescência densamente velutino (vs. hirsuto a densamente hirsuto), lâminas foliares mais largas (10,3-18 vs. 4,2-9 cm larg.), eglandulares (vs. com glândulas discoides pelo menos na face abaxial) $\mathrm{e}$ face adaxial bulada (vs. plana). Além disso, possui brácteas e bractéolas eglandulares (vs. com muitas glândulas na margem) e estames mais longos (19,522,5 vs. $11-14 \mathrm{~mm}$ compr.).

Um material proveniente do município de Itanhém (Amorim 4671) apresenta bractéolas com diminutas glândulas nas margens. Essa coleção foi aqui incluída no conceito de Hirtella prancei, porém é necessária a análise de outros materiais dessa população e, principalmente, observação dos indivíduos em campo para melhor entendimento desse caráter.

11. Hirtella racemosa Lam., Encycl. 3: 133. 1789.

Figuras 6E-H, 9F-H e 13; Aublet (1775: tab. 98) e Prance \& Sothers (2003b: fig. 73).

Árvores, arvoretas ou arbustos, 0,5-10 m alt; ramos jovens pubescentes, lenticelados. Folhas com lâmina ovada ou oblonga a estreitamente oblonga, base arredondada a subcordada ou cuneada, ápice agudo a atenuado, 3,6-8,7 × 1,8-4 cm, cartácea a coriácea, margem plana, 6-9 pares de nervuras secundárias; face abaxial esparsamente pubescente, nervuras 


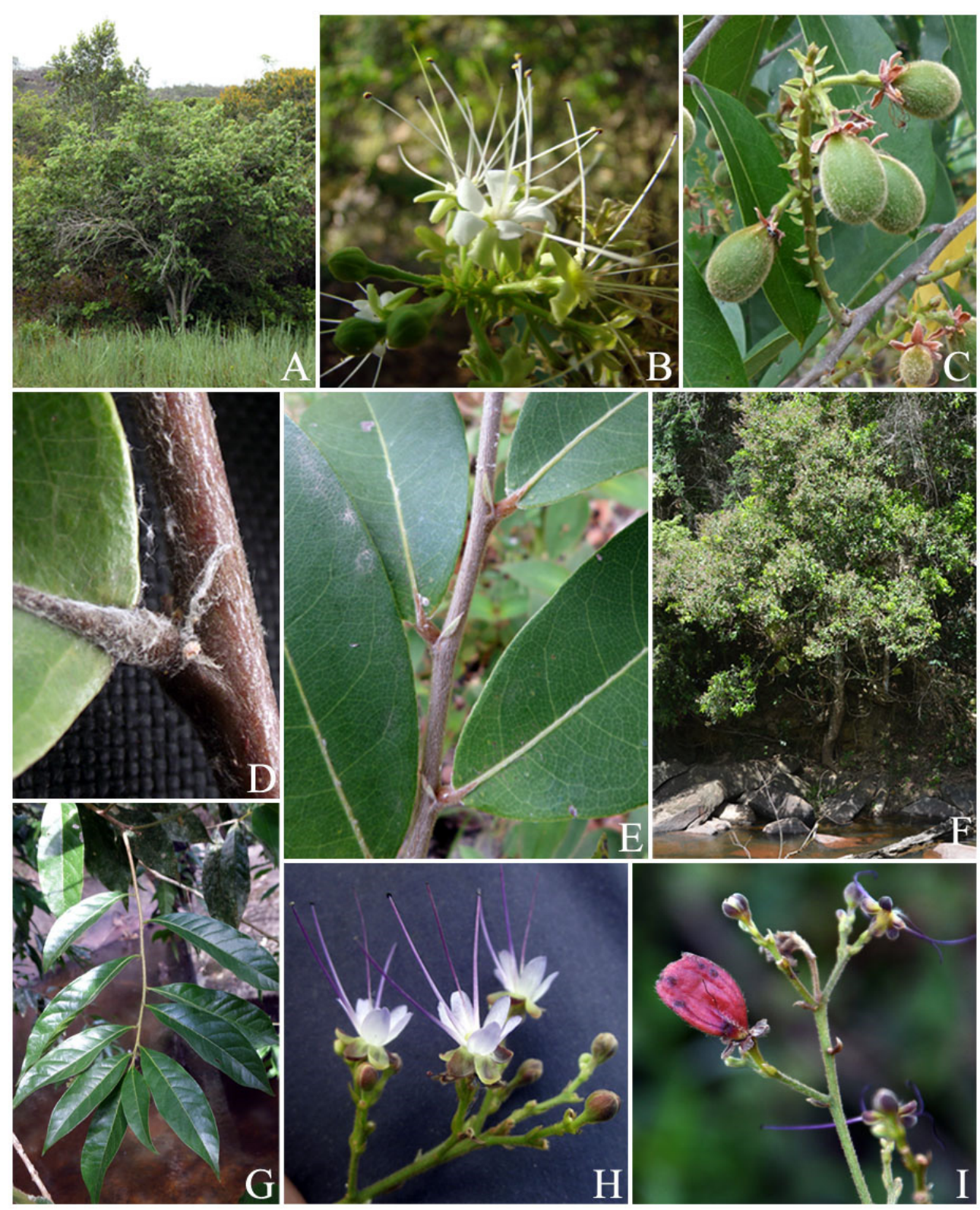

Figura 10. A-E. Hirtella martiana: A- hábito; B- detalhe da inflorescência com botões, flores em antese e flores passadas; C- frutos imaturos; D- detalhe do ramo e estípula; E- detalhe do ramo com estípulas e folhas em face adaxial. F-I. H. triandra: F- hábito; G- ramo com folhas em face adaxial; H- detalhe da inflorescência com botões e flores em antese; I- detalhe da inflorescência com botões, flores passadas e fruto imaturo. (Fotos A, C-G- R.C. Asprino; B- A. Stadnik; H- R.F. Almeida; I- C.S. Pessoa).

esparsamente pubescentes, glândulas discoides esparsas, nervura principal saliente, as secundárias levemente salientes; face adaxial glabrescente, nervuras esparsamente pubescentes, eglandular, nervuras principal a quaternárias levemente salientes; pecíolo 0,5-3 mm compr.; estípulas lineares, 3-6 $\mathrm{mm}$ compr., eglandulares. Inflorescências racemosas, $(6,5-$ )8-18,5 cm compr., pubescentes; brácteas estreitamente triangulares a lanceoladas, 1,5-3 $\mathrm{mm}$ compr., caducas, eglandulares, glândula séssil no ápice ou 2-6 na margem; pedicelos 3-11 mm compr., eglandulares ou com uma glândula estipitada próxima à base; bractéolas lineares a estreitamente elípticas, 0,5-1,5 mm compr., caducas, glândula séssil no ápice ou 2-6 na margem. Flores 5-6,5 $\mathrm{mm}$ compr; receptáculo cilíndrico; sépalas 3,5-4,5 mm compr., reflexas, ocasionamente glândulas na margem; pétalas 4-5 mm compr., róseas ou lilás; estames 5 ou $6,10-12$ $\mathrm{mm}$ compr., filetes róseos ou lilás; estilete ca. $10 \mathrm{~mm}$ compr., hirsuto apenas na base. Drupas elipsoides, 9$12 \times 6-8 \mathrm{~mm}$, epicarpo esparsamente pubescente.

Hirtella racemosa ocorre no México, diversos países da América Central e da América do Sul e, no Brasil, em todos os estados das Regiões Norte e Centro-Oeste, assim como nos estados do Ceará, Maranhão, Paraíba, Pernambuco, Sergipe e Bahia (Prance \& Sothers 2003b; Sothers et al. 2016). B9, C5, C6, D7, D10, E6, E7, E8, E9, E10: floresta ciliar em cerrado e campo rupestre, floresta estacional semidecidual, floresta ombrófila densa e restinga. 
Coletada com flores e frutos o ano todo, mais comumente em outubro e novembro.

Material selecionado - Alagoinhas, fazenda Limeira, ca. $8 \mathrm{~km}$ da cidade, $12^{\circ} 13^{\prime} \mathrm{S}, 38^{\circ} 21^{\prime} \mathrm{W}, 26$ fev. 2010 (fl., fr.), J.G. CarvalhoSobrinho et al. 2634 (HUEFS); Andaraí, BR-142 Km 155,

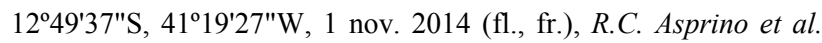
101 (HUEFS); Camaçari, estrada para o pólo petroquímico da Caraíba Metais, 1240'26"S, 38¹8'04"W, 19 nov. 2005 (fl., fr.), T.S. Nunes et al. 1329 (HUEFS, SPF); Campo Formoso, Serra da Boa Vista, $10^{\circ} 23^{\prime} \mathrm{S}, 41^{\circ} 14^{\prime} \mathrm{W}, 4$ set. 1981 (fl.), L.M.C. Gonçalves 188 (HRB); Conde, Fazenda do Bu, Mata do Bebedouro, 1202'24"S, 37²4'38"W, 10 nov. 1995 (fl., fr.), M.C. Ferreira \& T. Jost 839 (ALCB, CEPEC, HRB, HUEFS, MBM, RB); Dias d'Ávila, 12³6'45"S, 38¹7'49"W, 16 jan. 1961 (fl.), A.L. Costa s.n. (ALCB 1284); Elísio Medrado, Serra da Jibóia, fazenda Jequitibá, $12^{\circ} 52^{\prime} 05^{\prime \prime S}, 39^{\circ} 28^{\prime} 47^{\prime \prime} \mathrm{W}, 3$ mar. 2001 (fl., fr.), L.P. Queiroz et al. 6469 (CEPEC, HUEFS); Entre Rios, fazenda Rio do Negro, $12^{\circ} 01^{\prime}$ S, $38^{\circ} 02^{\prime} \mathrm{W}, 26$ out. 2010 (fl., fr.), A.V. Popovkin 775 (HUEFS); Esplanada, fazenda Chapada, caminho para Sítio do

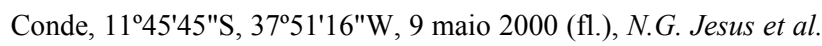
933 (ALCB, CEPEC, HRB, HUEFS, HUESC); Itanagra, fazenda Brejo Verde, $12^{\circ} 15^{\prime} 47^{\prime \prime S}, 38^{\circ} 02^{\prime} 30^{\prime \prime W}, 12$ jan. 1975 (fl.), E.F. Gusmão s.n. (ALCB 1285, HRB 31071); Jacobina, margem da

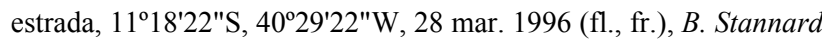
et al. 2618 (ALCB, CEPEC, HRB, HUEFS, SPF); Jandaíra, Areia

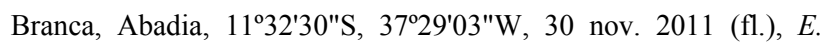
Matos \& G. Vidal 870 (HUEFS); Jeremoabo, comunidade Baixa dos Quelés, 0958'00"S, 38 26'00"W, 28 nov. 2009 (fl.), V.S. Almeida \& M.F. Santos 24 (HUEFS); Lençóis, Remanso/Marimbús, 12³9'S, 41 ${ }^{\circ} 19^{\prime} \mathrm{W}, 29$ jan. 1997 (fl.), S. Atkins et al. 4668 (ALCB, CEPEC, HRB, HUEFS, SPF); Maragogipe, Quilombo Salamina/Putumunju, 1266'S, 38 55'W, 15 abr. 2013 (fl.), M.S. Lisboa et al. 317 (ALCB); Mata de São João, Costa do Sauípe, fazenda Sauípe, 12³1'S, 38 $17^{\circ} \mathrm{W}, 17$ out. 2003 (fl., fr.), D.M. Loureiro et al. 743 (ALCB); Miguel Calmon, Parque Estadual das Sete Passagens, $11^{\circ} 23^{\prime} 18^{\prime \prime} \mathrm{S}, 40^{\circ} 32^{\prime} 08^{\prime \prime} \mathrm{W}, 4$ abr. 2001 (fl.), H.P. Bautista et al. 3004 (ALCB, CEPEC, HRB, HUEFS, HUESC); Muritiba, estrada para São Felipe, $12^{\circ} 05^{\prime} 05^{\prime \prime}$, 39 $39^{\circ} 02^{\prime} 05^{\prime \prime W}, 27$ maio 2003 (fl.), R.P. Oliveira et al. 909 (HUEFS); Palmeiras, Pai

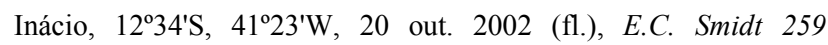
(HUEFS); Pilão Arcado, Barra do Brejo, na estrada para Brejo de Zacarias, $10^{\circ} 05^{\prime} 01^{\prime \prime S}, 42^{\circ} 50^{\prime} 16^{\prime \prime} \mathrm{W}, 7$ set. 2005 (fl.), L.P. Queiroz 10887 (HUEFS); Rio Real, ca. 7 km do entroncamento da BR-101

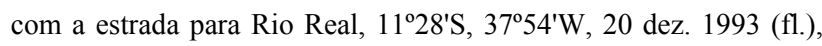
L.P. Queiroz \& N.S. Nascimento 3764 (HUEFS); Ruy Barbosa, Serra do Orobó, 12¹8'09"S, 40²9'11"W, 6 ago. 2001 (fl.), F.R. Nonato et al. 1021 (CEPEC, HUEFS); Salvador, Bairro de Mussurunga, Vila Verde, 1258'16"S, 38³0'39"W, 17 ago. 2010 (fl.), A.M. Miranda et al. 6186 (HUEFS); Santa Terezinha, Morro do Cruzeiro, 1246'19"S, 39³1'24"W, 2 set. 1995 (fr.), F. França et al. 1324 (CEPEC, HUEFS); São Sebastião do Passé, Lamarão do Passé, ao lado da represa, $12^{\circ} 30^{\prime} 45^{\prime \prime} \mathrm{S}, 38^{\circ} 29^{\prime} 43^{\prime \prime} \mathrm{W}, 18$ out. 1998 (fl.), A.F.S. Nascimento et al. 124 (ALCB); Umburanas, estrada para Boa Vista, após Delfino, 10²5'40"S, 4111'19"W, 25 set. 2004 (fl.), E.L. Borba et al. 2003 (HUEFS); Utinga, estrada para cachoeira Mariazinha, $12^{\circ} 01^{\prime} 57^{\prime \prime S}, 41^{\circ} 10^{\prime} 19^{\prime \prime} \mathrm{W}, 21$ set. 2007 (fl.), E. Melo et al. 5148 (HUEFS); Vera Cruz, fazenda OLDESA, Óleo de Dendê S.A., 1257'37"S, 38³6'31"W, 6 abr. 1999 (fr.), M.L. Guedes et al. s.n. (ALCB 41337).
Hirtella racemosa é uma das espécies mais comuns e amplamente distribuídas de Chrysobalanaceae (Prance 1972), e possui grande variação morfológica. Apresenta três variedades, $H$. racemosa var. racemosa, $H$. racemosa var. hexandra (Willd. ex Roem. \& Schult.) Prance e H. racemosa var. hispida Prance, que se diferenciam pelo indumento dos ramos jovens, comprimento e base da lâmina foliar, espessura e comprimento do pedicelo e glândulas nas bractéolas. No presente trabalho, optou-se por não adotar as categorias infraespecíficas, visto que é possível perceber sobreposição de caracteres em diversos materiais analisados.

Hirtella racemosa distingue-se das demais espécies que ocorrem na Bahia por apresentar ramos jovens com indumento pubescente, lâminas foliares ovadas ou oblongas a estreitamente oblongas, inflorescências racemosas, com bractéolas que possuem uma glândula séssil no ápice ou 2-6 na margem, além de flores com receptáculo cilíndrico e sépalas reflexas. Assemelha-se a H. gracilipes; as semelhanças e diferenças entre essas espécies são apresentadas nos comentários de $H$. gracilipes.

Três coleções provenientes do município de Pilão Arcado (Conceição 1474, Queiroz 10887 e Santos 1344) apresentam inflorescências atípicas, com forma congesta dos racemos até então não reportada para Hirtella racemosa. Essas coleções são aqui consideradas no conceito de $H$. racemosa, mas novos estudos e obtenção de novos registros dessa localidade são necessários para se esclarecer a identidade desses materiais.

12. Hirtella santosii Prance, Revista Brasil. Bot. 2: 34. 1979.

Figuras 9I, 11 e 12F-I; Prance (1979: fig. 5).

Árvores ou arvoretas, 4-20 m alt; ramos jovens hirsutos a densamente hirsutos, ocasionalmente lenticelados. Folhas com lâmina elíptica a oblonga ou ovada, base obtusa a arredondada ou cuneada, ápice atenuado a acuminado, 8,5-21,5 × 4,2-9 cm, cartácea, margem plana, 8-14 pares de nervuras secundárias; face abaxial hirsuta, nervuras hirsutas, glândulas discoides esparsas, nervuras principal e secundárias salientes; face adaxial esparsamente hirsuta, nervuras esparsamente hirsutas, ocasionalmente glândulas na base, nervura principal plana a impressa, as secundárias impressas, as terciárias planas ou impressas; pecíolo 2,5-8,5 $\mathrm{mm}$ compr.; estípulas estreitamente triangulares a triangulares, 2,5-6,5 mm compr., frequentemente glândulas na margem. Inflorescências racemosas, 4,5-12,5 cm compr., hirsutas a densamente hirsutas; brácteas estreitamente triangulares a triangulares, 1,5-3,5 mm compr., caducas, frequentemente glândulas sésseis diminutas na margem; pedicelos 6-19 mm compr., eglandulares; bractéolas ovadas a largamente ovadas, 0,5-2,5 mm compr., caducas, glândulas sésseis a curtamente estipitadas na margem. Flores 6-9,5 mm compr; 


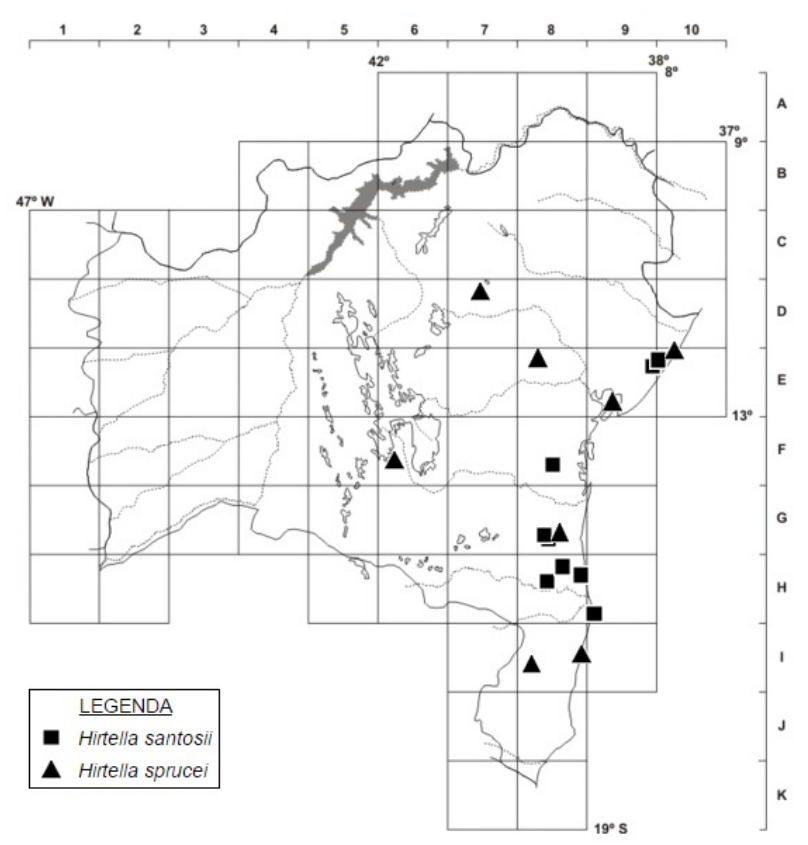

Figura 11. Distribuição geográfica de Hirtella santosii e H. sprucei no estado da Bahia.

receptáculo campanulado; sépalas 3,5-6,5 mm compr., eretas, ocasionalmente glândulas na margem; pétalas 2,5-4 mm compr., brancas; estames 5-7, 11-14 mm compr., filetes roxos; estilete 14-15 $\mathrm{mm}$ compr., hirsuto até o 1/3 basal. Frutos não vistos.

Hirtella santosii ocorre nos estados da Bahia e do Espírito Santo (Asprino \& Amorim 2016). E9, G8, F8, H8, H9: floresta ombrófila densa. Coletada com flores de outubro a fevereiro.

Material selecionado - Almadina, Serra do Corcovado, 14²4'44"S, 39³6'10"W, 23 nov. 2014 (fl.), R. Asprino et al. 112 (CEPEC); Arataca, RPPN Caminho das Pedras, Serra do Peito de Moça, 15²10'27"S, 39²0'22"W, 25 nov. 2006 (fl.), A.M. Amorim et al. 6562 (CEPEC, HUESC); Barro Preto, Serra da Pedra Lascada, 1446'13"S, 39³2'10"W, 10 dez. 2005 (fl.), J.G. Jardim et al. 4791 (CEPEC, RB, SPF); Belmonte, Estação Experimental Gregório Bondar-CEPLAC, 1551'47"S, 3852'58"W, 29 nov. 1987 (fl.), T.S. Santos 4343 (CEPEC); Camacan, RPPN Serra Bonita, 15'23'30"S, 39³3'55"W, 17 jul. 2009 (est.), A.M. Amorim et al. 7891 (CEPEC); Entre Rios, Algodões, $12^{\circ} 10^{\prime} 00^{\prime \prime S}, 37^{\circ} 58^{\prime} 00^{\prime \prime W}, 28$ out. 2014 (fl.), A.V. Popovkin \& J.C. Mendes 1807 (HUEFS); Itanagra, fazenda Brejo Verde, $12^{\circ} 15^{\prime} 47^{\prime \prime S}, 38^{\circ} 02^{\prime} 30^{\prime \prime} \mathrm{W}, 17$ nov. 1974 (fl.), E.F. Gusmão s.n. (ALCB 1289, CEPEC 60516, HRB 31072, HUEFS 15450); Una, fazenda São Rafael, 15²17'36"S, 3904'31"W, 10 dez. 1968 (fl.), T.S. Santos 300 (holótipo CEPEC); Wenceslau Guimarães, Reserva Estadual de Wenceslau Guimarães, 13²41'13"S, 39²8'46"W, dez. 2015 (fl.), A.M. Amorim et al. 10133 (CEPEC, HUEFS).

Hirtella santosii pode ser reconhecida por apresentar ramos jovens, pecíolos e inflorescências com indumento hirsuto a densamente hirsuto, face abaxial das folhas hirsuta e com glândulas discoides esparsas, inflorescências racemosas com bractéolas ovadas a largamente ovadas que possuem glândulas em toda a margem. Em diversas amostras, é nítida a presença de diminutas glândulas na margem das estípulas, característica ainda não reportada para essa espécie. Assemelha-se a H. prancei; as semelhanças e diferenças entre essas espécies são apresentadas nos comentários de $H$. prancei.

Dois registros provenientes do município de Entre Rios (Popovkin 445, 817) apresentam morfologia distinta da maioria das coleções aqui mencionadas. Nessas amostras, os ramos, inflorescências e lâminas foliares apresentam indumento pubescente (vs. hirsuto a densamente hirsuto), pecíolos mais curtos (1-2,5 mm vs. 2,5-8,5 $\mathrm{mm}$ compr.) e flores com receptáculo cilíndrico (vs. campanulado). Entretanto, não foram obtidas amostras com flores bem desenvolvidas desses materiais e, desse modo, eles se mantêm dentro do conceito de Hirtella santosii.

Hirtella hebeclada Moric. ex DC. teve sua ocorrência registrada na Bahia por Prance \& Sothers (2003b). Entretanto, durante o desenvolvimento do presente estudo foi constatado que esses registros se referem a espécimes de $H$. santosii erroneamente identificados (Asprino \& Amorim 2016).

13. Hirtella sprucei Benth. ex Hook.f., F1. Bras. 14(2): 31. 1867.

Figura 9J, K e 11; Hooker (1867: tab. 9).

Árvores, arvoretas ou arbustos, 1-8 m alt.; ramos jovens esparsamente hirsutos a glabrescentes, não lenticelados. Folhas com lâmina estreitamente oblonga a oblonga, base arredondada a subcordada ou truncada, ápice atenuado a acuminado ou agudo, 9,2-16,7 $\times$ $(2,8-) 3,2-4,9 \mathrm{~cm}$, cartácea, margem plana, 9-11 pares de nervuras secundárias; face abaxial glabrescente, nervuras esparsamente hirsutas, glândulas discoides esparsas, nervural principal saliente, as secundárias levemente salientes; face adaxial glabrescente, nervuras glabrescentes, eglandular, nervuras principal a quaternárias levemente salientes; pecíolos 2-5 $\mathrm{mm}$ compr.; estípulas lineares, 6-7(-10) $\mathrm{mm}$ compr., eglandulares. Inflorescências racemosas, 10-29 cm compr., esparsamente pubescentes ou hirsutas; brácteas estreitamente triangulares, 1,2-2 $\mathrm{mm}$ compr., caducas, eglandulares; pedicelos 4-6,5 mm compr., 1 ou 2 glândulas estipitadas próximas à base; bractéolas reduzidas a glândula(s) estipitada(s) no pedicelo, ca. 0,5 mm compr., persistentes. Flores 5-6 mm compr.; receptáculo estreitamente campanulado; sépalas 3,5-4 $\mathrm{mm}$ compr., reflexas, margem eglandular; pétalas 33,5 $\mathrm{mm}$ compr., róseas; estames 5 ou $6,13-18 \mathrm{~mm}$ compr., filetes róseos; estilete 14-20 mm compr., hirsuto até o 1/4 basal. Drupa elipsoide, ca. $24 \times 12$ $\mathrm{mm}$, epicarpo glabrescente.

Hirtella sprucei ocorre nos estados do Mato Grosso, Rio de Janeiro, Espírito Santo, Minas Gerais e Bahia (Prance \& Sothers 2003b; Sothers et al. 2016). D7, E8, E9, E10, F6, G8, I8: floresta ciliar em campo rupestre e formações estacionais, e floresta ombrófila densa. Coletada com flores ao longo do ano e com frutos em janeiro, abril e julho. 

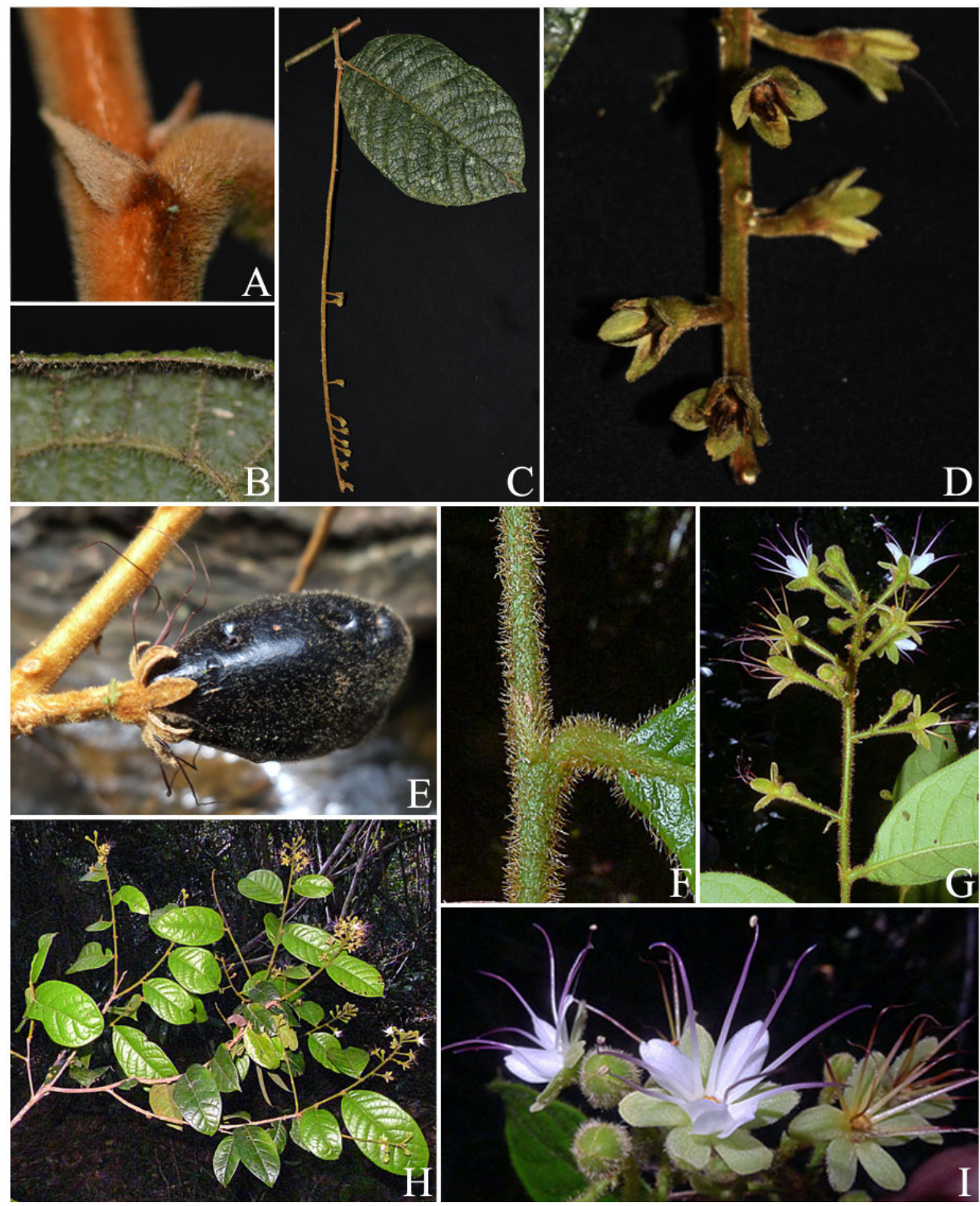

Figura 12. A-E. Hirtella prancei: A- detalhe do ramo e estípula; B- detalhe da margem da folha; C- folha apical e inflorescência; D- detalhe da inflorescência com flores passadas; E- fruto maduro, vista lateral. F-I. H. santosii: F- detalhe do ramo e estípula; G- inflorescência com botões, flores em antese e flores passadas; H- ramo com folhas e inflorescências; I- detalhe da inflorescência com botões, flores em antese e flores passadas. (Fotos A-D- A.M. Amorim; E- R.C. Asprino; F-I- A.V. Popovkin).

Material selecionado - Conde, Fazenda do Bu, Mata da Maré, $12^{\circ} 02^{\prime} 07^{\prime \prime S}, 37^{\circ} 43^{\prime} 43^{\prime \prime W}, 7$ dez. 1997 (fl.), M.C. Ferreira et al. 1242 (ALCB, CEPEC, HRB, MBM, RB); Guaratinga, rodovia Guaratinga-São Paulinho Km 25, 16³5'32"S, 3946'58"W, 5 abr. 1973 (fl.), R.S. Pinheiro 2096 (CEPEC); Ipirá, Reserva da Caboronga, $12^{\circ} 08^{\prime} 54^{\prime \prime S}, 39^{\circ} 41^{\prime} 46^{\prime \prime} \mathrm{W}, 4$ ago. 2013 (est.), D.M. Neves et al. 1591 (HUEFS); Itajuípe, $18 \mathrm{~km}$ ao sul de Itajuípe, fazenda Santo Antônio, 14\%40'41"S, 39²2'30"W, 4 fev. 1970 (fl.), T.S. Santos 570 (CEPEC); Jacobina, $11^{\circ} 10^{\prime} 50^{\prime \prime S}, 40^{\circ} 31^{\prime} 06^{\prime \prime} \mathrm{W}, 1845$ (fl.), J.S. Blanchet 3568 (holótipo K n.v., isótipo P foto); Porto Seguro, Parque Nacional Monte Pascoal, 16 266'59"S, 3903'53"W, 14 nov. 1996 (fl.), W.W. Thomas et al. 11260 (CEPEC); Rio de

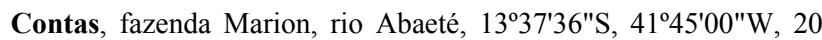
abr. 2003 (fl., fr.), R.M. Harley \& A.M. Giulietti 54626 (HUEFS);

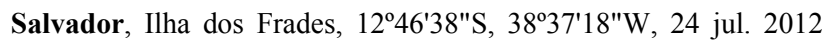
(fl., fr.), E.P. Queiroz et al. 5428 (ALCB).
Hirtella sprucei pode ser reconhecida por apresentar as lâminas foliares estreitamente oblongas a oblongas, indumento esparsamente hirsuto a glabrescente nos ramos jovens e pecíolo, estípulas lineares, inflorescências racemosas e pedicelos com 1 ou 2 glândulas estipitadas. Assemelha-se a $H$. angustifolia; as semelhanças e diferenças entre essas espécies são apresentadas nos comentários de $H$. angustifolia.

\section{Hirtella triandra Sw., Prodr. 51. 1788.}

Figuras 10F-I e 13; Pennington (2004: fig. 255).

Árvores, 4-30 m alt.; ramos jovens esparsamente pubescentes, lenticelados. Folhas com lâmina elíptica a estreitamente elíptica, base aguda a cuneada, ápice atenuado a acuminado, 6,4-11,8 $\times$ 2,4-4,5 cm, 
cartácea, margem plana, 8-10 pares de nervuras secundárias; face abaxial glabrescente, nervuras esparsamente pubescentes, glândulas discoides na base, nervura principal saliente, as secundárias levemente salientes; face adaxial glabrescente, nervuras glabrescentes, eglandular, nervura principal levemente saliente; pecíolo 1,5-2,5 mm compr.; estípulas lineares a estreitamente triangulares, 5-5,5 $\mathrm{mm}$ compr., eglandulares. Inflorescências paniculadas, 5-18 cm compr., pubescentes; brácteas estreitamente triangulares a triangulares, 3-5 $\mathrm{mm}$ compr., persistentes, ocasionalmente glândulas sésseis diminutas na margem; pedicelos 2-5 $\mathrm{mm}$ compr., eglandulares; bractéolas estreitamente triangulares a triangulares, 2-3 $\mathrm{mm}$ compr., persistentes, ocasionalmente glândulas sésseis diminutas na margem. Flores 5-7 $\mathrm{mm}$ compr., receptáculo campanulado; sépalas 4-5 $\mathrm{mm}$ compr., reflexas, margem eglandular; pétalas 5-6 $\mathrm{mm}$ compr., brancas com ápice roxo-azulado; estames 3, ca. $18 \mathrm{~mm}$ compr., filetes roxo-azulados; estilete ca. $18 \mathrm{~mm}$ compr., hirsuto até o 1/3 basal. Drupas obovoides, 19$24 \times 11-12 \mathrm{~mm}$, epicarpo esparsamente pubescente, endocarpo pubescente.

Hirtella triandra ocorre no México, em diversos países da América Central e da América do Sul, e no Brasil, em quase todos os estados da Região Norte, assim como nos estados do Rio de Janeiro, Espírito Santo, Minas Gerais e Bahia (Prance \& Sothers 2003b; Sothers et al. 2016). G7, G8, H8, I8: floresta ombrófila densa. Coletada com flores em janeiro, março, abril e de outubro a dezembro, e com frutos em janeiro, março, outubro e novembro.

Material selecionado - Boa Nova, estrada de terra entre Valentim e Boa Nova, 14'21'18"S, 4005'30"W, 30 nov. 2014 (fl., fr.), R. Asprino et al. 114 (HUEFS); Camacan, estrada para Rio Branco, 1525'09"S, 39²9'45"W, 28 jan. 1971 (fl., fr.), T.S. Santos 1441 (CEPEC, RB); Ilhéus, área do CEPEC, quadra D, 14²4'20"S, 3902'57"W, 16 dez. 1982 (f1.), T.S. Santos 3828 (CEPEC, HUEFS); Jussari, Estação Experimental Gileno Amado, 15\%11'29"S, 39²9'43"W, 5 maio 1988 (est.), L.A. Mattos-Silva et al. 2410 (CEPEC, HRB); Porto Seguro, Parque Nacional do Monte Pascoal, 1626'59"S, 3903'53"W, 15 jan. 1973 (fl., fr.), T.S. Santos 2693 (CEPEC, RB).

Hirtella triandra apresenta três subespécies, $H$. triandra subsp. triandra, $H$. triandra subsp. media (Standl.) Prance e H. triandra subsp. punctulata (Miq.) Prance, que se diferenciam pelo comprimento, ápice e textura da lâmina foliar, quantidade de nervuras secundárias, e grau de ramificação da inflorescência. No presente trabalho, categorias infraespecíficas não foram adotadas, visto que é frequente a sobreposição dos caracteres que as diferenciam.

Hirtella triandra se diferencia das demais espécies de Hirtella que ocorrem na Bahia por apresentar os ramos jovens esparsamente pubescentes, folhas com lâmina elíptica a estreitamente elíptica, de base aguda a cuneada, cartácea, e estípulas de 5-5,5 $\mathrm{mm}$ compr. caducas, inflorescências paniculadas com brácteas e

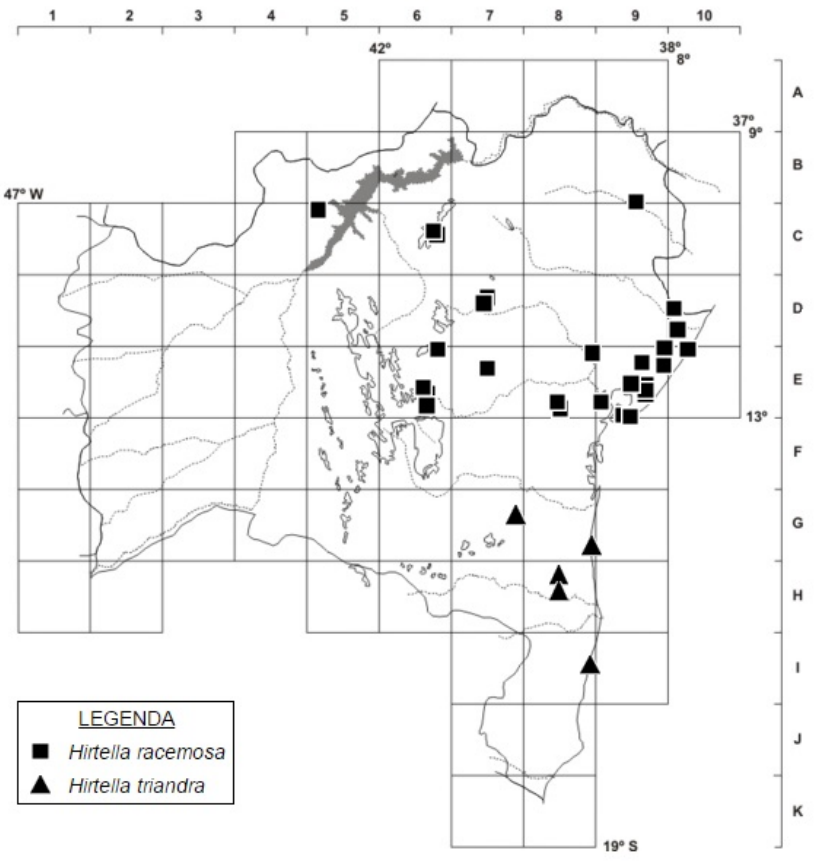

Figura 13. Distribuição geográfica de Hirtella racemosa e H. triandra no estado da Bahia.

bractéolas estreitamente triangulares a triangulares, persistentes, além de flores com apenas três estames.

\section{Agradecimentos}

Agradecemos aos autores das fotos, gentilmente cedidas. AMA é financiado pelo CNPq (Bolsa PQ 310717/2015-9; Edital Reflora 563548/2010-0 e Edital Universal 486079/2013-9). A execução dessa pesquisa foi viabilizada pelo $\mathrm{CNPq}$ através da concessão de bolsa de mestrado (133493/2014-8) para RCA.

\section{REFERÊNCIAS}

Asprino, R.C. \& Amorim, A.M.A. 2016. A new species of Hirtella (Chrysobalanaceae), and redescription of a closely related taxon, from the Atlantic Forest, Brazil. Phytotaxa 265(3): 259-266.

Aublet, J.B.C.F. 1775. Histoire des Plantes de la Guiane Françoise. Vol 1. Didot, London \& Paris.

Hooker, J.D. 1867. Rosaceae: Chrysobalaneae. In: C.F.P. Martius (ed), Flora Brasiliensis. Vol. 14, part. II. Frid. Fleischer, Leipzig, p. 5-56; tab. 1-18.

Pennington, T.D.; Reynel, C. \& Daza, A. 2004. Chrysobalanaceae. In: Illustrated Guide to the Trees of Peru. David Hunt, Sherborne.

Prance, G.T. 1972. Chrysobalanaceae. In: H.S. Irwin (ed.), Flora Neotropica Monograph 9. Hafner Publishing Company, New York.

Prance, G.T. 1979. The taxonomy and phytogeography of the Chrysobalanaceae of the Atlantic coastal forests of Brazil. Revista Brasileira de Botânica 2(1): 19-39. 
Prance, G.T. 1988. Chrysobalanaceae. In: J.A. Rizzo (org.), Flora do Estado de Goiás. Vol. 10. Editora Universidade Federal de Goiás, Goiânia.

Prance, G.T. 2003. Chrysobalanaceae. In: M.G.L. Wanderley, G.J. Shepherd, A.M. Giulietti \& T.S. Melhem (eds), Flora Fanerogâmica do Estado de São Paulo. Vol. 3. Instituto de Botânica, São Paulo, p. 33-44.

Prance, G.T. \& Sothers, C.A. 2003a. Chrysobalanaceae 1: Chrysobalanus to Parinari. In: A.E. Orchard \& A.J.G. Wilson (eds), Species Plantarum: Flora of the World 9. Australian Biological Resources Study, Canberra.

Prance, G.T. \& Sothers, C.A. 2003b. Chrysobalanaceae 2, Acioa to Magnistipula. In: A.E. Orchard \& A.J.G. Wilson (eds), Species Plantarum: Flora of the World 10. Australian Biological Resources Study, Canberra.

Prance, G.T. \& White, F. 1988. The genera of Chrysobalanaceae: a study in practical and theoretical taxonomy and its relevance to evolutionary biology. Philosophical Transactions of the Royal Society B320(1197): 1-184.

Sothers, C.A.; Prance, G.T.; Buerki, S.; Kok, R. \& Chase, M.W. 2014. Taxonomic novelties in neotropical Chrysobalanaceae: towards a monophyletic Couepia. Phytotaxa 172(2): 176-200.

Sothers, C.; Alves, F.M. \& Prance, G.T. 2016. Chrysobalanaceae. In: Lista de Espécies da Flora do Brasil. Jardim Botânico do Rio de Janeiro. Disponível em http://reflora.jbrj.gov.br/jabot/ floradobrasil/FB85; acesso em 25 jan. 2016.

Xi, Z.; Ruhfel, B.R.; Schaefer, H.; Amorim, A.M.; Sugumaran, M.; Wurdack, K.J.; Endress, P.K.; Matthews, M.L.; Stevens, P.F.; Mathews, S. \& Davis, C.C. 2012. Phylogenomics and a posteriori data partioning resolve Cretaceous angiosperm radiation Malpighiales. Proceedings of the National Academy of Science of the United States of America 109(43): 17519-17524.

\section{LiSTA DE EXSICATAS}

Abreu, L.S. 64 (6); Adorno, H. 85 (11); Agobar, M. 1, 4 (7), 16 (6); Almeida, V.S. 24 (11), 80 (4); Alves, L.J. 16 (11), 144 (2); Alves, M. 960 (6); Amorim, A.M. 536 (6), 848 (1), 1588 (3), 1620 (1), 1666 (6), 1756, 1783 (11), 3514 (4), 3837 (11), 6562,7891 (12), 7910,9760 (10); Anjos, B.A. 55 (4); Aparecida da Silva, M. 1317; 3521 (4); Araújo, A.P. 220 (11); Araújo, G. 161 (4), 324 (7); Araújo, J. S. 104 (11); Arouck, J. 146, 221 (4); Asprino, R. 61 (10), 85 (9), 86 (6), 88, 89 (7), 99, 100 (6), 101 (11), 112 (12), 114 (14), 117 (10), 121 (3); Atkins, S. 4668 (11); Barbosa, E. 2799 (6), 2802 (11); Bautista, H.P. 1006 (11), 1324 (6), 1516 (4), 1523 (6), 3004 (11), 3095 (4), 3302 (9); Belém, R.P. 633 (14), 771 (6), 2756, 3094 (2); Bezerra, M. 1 (4); Blanchet J.S. 3568 (13); Blanchet, M. 1841 (4); Borba, E.L. 2003 (11), 2006 (4), 2024 (6); Borges, R.A.X. 863 (1); Bridgewater, S. 1023 (4); Cardoso, D. 183 (4), 232, 315 (11); Carneiro, J. 1703 (6); Carneiro-Torres, D.S. 248 (6); 547 (4); Carvalho, A.M. 469 (6), 647 (1), 1046 (6), 2379, 2827, 3028 (11), 3377 (1), 3917 (4), 4190,7062 (11); Carvalho-Sobrinho, J.G. 2634 (11), 2708 (4); Cavalcante, T. 1 (4); Coelho, M.M. 538, 624 (12); Collares, J.E.R. 110 (4); Conceição, A.A. 1474 (11), 2019 (6), 2032 (9), 2151 (4), 2160 (6), 2354 (9), 2378 (6); Coradin, L. 6471 (11); Costa, A.L. s.n. ALCB 1284 (11), s.n. ALCB 1288 (4), s.n. ALCB 1292, s.n. ALCB 4749 (11), s.n. HUEFS 15448 (4); Costa, J. 83 (11), 383 (4); Costa, T.A.B. 10 (11); Cotrim, A. 341 (4), 1084, 1144, 1145 (6); Couto, A.P.L. 98, 180 (6), 205, 237 (11); Couto, F.S. 1 (11); Dâmaso, V. 8 (7); Duarte, A.P. 6014 (2), 6645 (6), 8029 (2), 9328 (11); Dutra, V.F. 758 (6); Esteves, F. s.n. ALCB 25074 (6); Eupunino, A. 195 (13), 212 (8), 361 (3); Farney, C. 2617 (5); Ferreira, J.L. 138 (11); Ferreira, M.C. 636 (4), 839 (11), 1242 (13), 1264 (4), 1890 (11); Fiaschi, P. 2065 (1); Flores, T.B. 501 (11); Folli, D.A. 884 (14), 6205 (6); Fonseca, M.L. 509, 2885 (4); Fonseca, M.R. s.n. ALCB 51885 (4); Fonseca-Neto, F.P. 51 (4); Forzza, R.C. 1300, 1324 (11), 1413 (4), 3893 (11); Fraga, C.N. 2749 (7); França, F. 1324 (11), 1581 (6), 1697 (4), 2632,2673 (11), 2877 (4), 3218 (11), 3612 (7), 5628 (6); Freire-Fierro, A. 2072 (11); Freitas, J.G. 714 (11); Funch, L.S. 110 , 115 (6); Funch, R. 18/02 (6), 51/02 (11); Furlan, A. 7138 (6); Ganev, W. 490 (6), 1070, 1223 (9), 1264, 1861 (6), 2233 (9); Gasson, P. 6212 (11); Giulietti, A.M. 1397 (9), 6760 (6); Gomes, F.S. 12, 244 (4), 455 (6), 644 (11), 673, 856 (4); Gonçalves, L.M.C. 188 (11); Gouvea, E. 3/88, s.n. ALCB 21894 (6); Grillo, A.A. 91 (6); Groppo Jr., M. 1033 (11); Grupo Pedra do Cavalo 612 (7); Guedes, M.L. 376 (11), 825 (4), 1231 (11), 1411 (6), 1418 (11), 1457 (6), 2573, 2896 (11), 3164, 3659 (4), 3829 (11), 3958 (4), 4865 (11), 5472 (6), 6587, 6603 (4), 7488 (6), 8308, 9336 (4), 9340 (11), 10481, 10922, 11017, 11020, 11224, 11573 (4), 13017, 13137 (11), 13405, 13433, 13576, 13614 (7), 13635 (9), 13707 (7), 13780 (6), 14143 (7), 14183, 14561 (6), 14641 (4), 14643, 14647, 14791, 16853, 17934 (11), 17974, 18127, 18463 (4), 18503 (11), 19964 (6), 19980 (11), 20104 (6), 20238 (4), 20352, 20755 (11), 21306 (4), 21560, 21687, s.n. ALCB 26178, s.n. ALCB 41337 (11), s.n. ALCB 61420 (3), s.n. ALCB 76762 (11), s.n. ALCB 82632 (4), s.n. ALCB 104828 (11); Gusmão, E.F. 386 (4), s.n. ALCB 1285 (11), s.n. ALCB 1289 (12); Hage, J.L. 285 (6), 564 (14); Harley, R.M. 4436, 6094 (6), 7515 (4), 17370 (6), 18256 (8), 18581 (6), 18585 (11), 19058 (4), 20074 (6), 21649 (7), 21779 (4), 21834 (7), 22440 (11), 25387, 26116 (6), 27586 (4), 28351 (9), 28426 (2), 50334 (6), 54626 , 55432 (13), 56155, 56160 (9); Hatschbach, G. 44112 (4), 47027, 47791 (5), 50119 (11), 50525 (4), 53367 (6), 53410 (9); Hind, N. 4256 (6), 4262 (9); Jardim, J.G. 690, 715 (11), 877 (7), 882 (6), 900 (4), 2276 (3), 2992, 3078 (1), 3707 (6), 4791 (12), 5454 (3); Jesus, J.A. 185 (14), 594 (6); Jesus, N.G. 28 (11), 159 (2), 240 (3), 933 (11), 1564 (4); Jost, T. 116, 135 (4), 255 (11); Juncá, F.A. 3 (11); Kuhn-Neto, R. 10 (4); Labiak, P.H. 6084 (11); Leite, K.R.B. 27 (4); Lemos, M.J.S. 89 (11); Lima, A.F.B. s.n. ALCB 26219 (11); Lima, H.C. 3944,7886 (4), s.n. RB 298394 (11); Lisboa, M.S. 317 (11); Lopes, M.M.M. 945 (8); Loureiro, D.M. 54 (11), 97 (6), 184 (11), 303 (4), 394 (10), 743 (11), 745 (4); Lutzelburg 1822 (7); Maas, P.J.M. 7039 (8); Maliarenko, L. 13 (4); Marinho, L.C. 938 (4); Marquete, R. 2064 (11); Martinelli, G. 5325 (6), 5387 (11), 9649 (6); Martini, A. s.n. CEPEC 122605 (3), s.n. CEPEC 122819 (2); Matos, E. 481 (5), 827 (4), 870 (11), 997 (6), 1012, 2545 (4), 3389 (8); Matos, V.R. 31 (11); Matos-Andrade, P.E. 3 (4); Mattos-Silva, L.A. 390,1586 (6), 1668 (8), 2410 (14), 2764 (6), 3074 (10), 5110 (6); Mayo, S.J. 1116 (6); Melo, E. 1357 (11), 2704 (4), 2793 (6), 4263 (4). 5132,5148 (11), 5312,5986 (6), 7933, 8706 (4); Mello-Silva, R. 7548 (4); Menezes, C.M. 201 (4), 397, 398 (8); Miranda, A.M. 4187 (9), 4266, 5391 (4), 6186 (11); Miranda, E.B. 11, 25 (11), 375 (7), 490 (6); Miranda, L.A.P. 99 (6); Monteiro, M.T. 23674 (8); Moraes, E.P.F. 19 (11); Moraes, M.V. 
498 (4); Mori, S.A. 10470 (5), 10936 (2), 12296 (6), 12354 (9), 12932, 13098 (6); Nascimento, A.F.S. 124, 185 (11); Nascimento, F.H.F 217, 218 (6); Neves, D.M. 1541 (4), 1591 (13); Neves, L.M.C. 19 (11); Noblick, L.R. 1330 (11), 2864 (6), 2164 (4), 2478 (11), 3088 (4); Nonato, F.R. 850, 875, 1021 (11); Nunes, M.S. 26 (11); Nunes, T.S. 167 (6), 215 (11), 962 (4), 1329 (11); Oliveira, A.A. 214 (7); Oliveira, D.S.C. 6 (4); Oliveira, M. 3038 (4); Oliveira, R.B. 53 (2); Oliveira, R.P. 909 (11); Orlandi, R.P. 158 (4); Pacheco, L.M. 57 (2); Paixão, J.L. 331 (2); Paraguassú, L. 08/92 (4); Paula-Souza, J. 9287, 9288 (4); Paulon, M.A. 1 (11); Pereira, A. 9 (11); Pereira, E. 2034 (6), 10041 (11); Pinheiro, R.S. 1016, 1177 (14), 2096 (13), 2120 (5); Pinto, G.C.P. 13/86, 19/92 (11), 70/81, 193/80 (4), $242 / 73$ (6), $280 / 81$ (11), 328/81, s.n. ALCB 1290 (6); s.n. ALCB 6061 (11); Pirani, J.R. 461 (6); Popovkin, A.V. 187 (11), 445 (12), 775 (11), 817 (12), 963 (4), 1807 (12); Prates, A.R. 281 (4); Queiroz, E.P. 371, 402 (8), 2392 (11), 2632 (8), 2815 (6), 2922 (11), 2935 (4), 2937 (11), 3286,3356 , 3485 (4), 3936 (6), 3950 (11), 5428 (13); Queiroz, L.P. 902, 1213, 1475 (4), 1825 (11), 1827 (6), 3764 (11), 3779 (4), 4087 (6), 4145 (4), 4217 (6), 4229 (11), 5367 (4), 5488 (11), 6348 (9), 6469 (11), 7140 (6), 9421 (11), 9422 (6), 9528 (11), 9539 (6), 9544 (11), 9718,9776 , 9858 (6), 11011 (7), 14842 (4), 16034 (6); Ramalho, F.B. 32 (6), 124 (9), 145 (6); Ramos, C.E. 209 (1); Ratter, J.A. 8048 (4); Rezende, S.G. 1657 (8); Ribeiro, A.G. 161 (4); Ribeiro, A.J. 63 (11); Ribeiro, T. 188 (11), 363 (6); Rigueira, D. s.n. ALCB 74628 (6); Roque, N. 919 (6), 2500, 2539, 2566, 3002 (11), 4015 (6); Rosas, E. 15 (11); Sambuichi, R. 377 (14); Santana, D.L. 190 (6), 625 (3); Sant'Ana, S.C. 82 (6), 84 (2), 194 (14), 1005 (6); Santino 284 (7); Santos, A.K.A. 346 (11), 497, 504, 512 (4); Santos, A.P.B. 80 (5); Santos, E.C. 20 (9); Santos, R.B. 12, 33 (6); Santos, R.M. 1344 (11); Santos, T.S. 300 (12), 526 (14), 570 (13), 1284 (2), 1402 (6), 1441 (14), 1677,1695 (8), 2287 (6), 2693 (14), 2898 (8), 2984 (6), 3828 (14), 4343 (12), 4389 (6); Sarmento, A. C. 884 (6); Sessegolo 89, 99 (11); Silva, A.T. s.n. HUEFS 58627 (6); Silva, L.N. 35 (11); Silva, M.M. 480 (6); Silva, S.B. 383 (4); Silva-Castro, M.M. 1096 (6); Smidt, E.C. 259 (11); Soeiro, R. 49/96 (11); Sobral, M. 8445 (4); Souza, V.C. 26136 (6); Stannard, B. 2618 (11); Stefane, R. 139 (7); Vidal, J. s.n. R 35180 (4); Stradmann, M.T.S. 153, 220 (6), 504 (4), 752 (6); Thomas, W.W. 6024, 7194 (8), 7508, 8227 (2), 8923 (8), 9664 (4), 10212 (8), 11260 (13), 12008 (8), 12015, 14132 (3); Torrena, P.C. s.n. ALCB 1287 (4); Violatti, L.G. 19 (4); Voeks, R. 72 (2); Woodgyer, E. 2771 (11), 2841 (4); Xavier, A.B. 199 (4); Zehntner, L. 401 (7), 632 (6). 